\title{
GLASS FABRICATION AND PRODUCT CONSISTENCY TESTING OF LANTHANIDE BOROSILICATE FRIT B COMPOSITION FOR PLUTONIUM DISPOSITION
}

James C. Marra

Charles L. Crawford

Ned E. Bibler

January 2006

Savannah River National Laboratory Aiken, SC 29808

Prepared for the U.S. Department of Energy Under Contract Number DEAC09-96SR18500
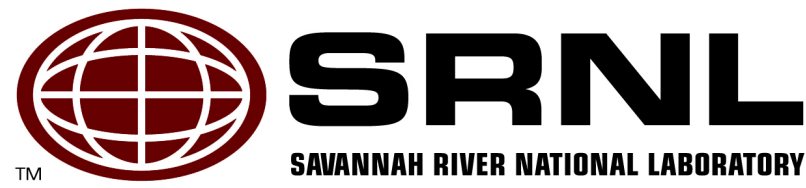
WSRC-TR-2006-00033

Revision 0

\section{DISCLAIMER}

This report was prepared by Washington Savannah River Company (WSRC) for the United States Department of Energy under Contract No. DE-AC09-96SR18500 and is an account of work performed under that contract. Neither the United States Department of Energy, nor WSRC, nor any of their employees makes any warranty, expressed or implied, or assumes any legal liability or responsibility for the accuracy, completeness, or usefulness, of any information, apparatus, or product or process disclosed herein or represents that its use will not infringe privately owned rights. Reference herein to any specific commercial product, process, or service by trademark, name, manufacturer or otherwise does not necessarily constitute or imply endorsement, recommendation, or favoring of same by WSRC or by the United States Government or any agency thereof. The views and opinions of the authors expressed herein do not necessarily state or reflect those of the United States Government or any agency thereof.

\section{Printed in the United States of America}

Prepared For

U.S. Department of Energy 
Key Words: Plutonium disposition,

Plutonium glass durability, Leach testing

Retention: Permanent

\section{GLASS FABRICATION AND PRODUCT CONSISTENCY TESTING OF LANTHANIDE BOROSILICATE FRIT B COMPOSITION FOR PLUTONIUM DISPOSITION}

James C. Marra

Charles L. Crawford

Ned E. Bibler

January 2006 


\section{REVIEWS AND APPROVALS}

\section{$\operatorname{AUTHOR(S):~}$}

\begin{tabular}{ll}
\hline James C. Marra, Materials Science and Technology Date &
\end{tabular}

Charles L. Crawford, Process Science and Engineering

Date

Ned E. Bibler, Process Science and Engineering

Date

\section{TECHNICAL REVIEWER:}

\begin{tabular}{lc}
\hline David Peeler, Process Science and Engineering & Date
\end{tabular}

\section{APPROVERS}

Natraj C. Iyer, Director, Materials Science and Technology

Date

Richard E. Edwards, Manager, Process Science and Engineering

Date

Matthew K. Hackney, Nuclear Materials Management Engineering

Date 


\section{EXECUTIVE SUMMARY}

The Department of Energy Office of Environmental Management (DOE/EM) plans to conduct the Plutonium Disposition Project at the Savannah River Site (SRS) to disposition excess weapons-usable plutonium. A plutonium glass waste form is a leading candidate for immobilization of the plutonium for subsequent disposition in a geologic repository. A reference glass composition (Lanthanide Borosilicate (LaBS) Frit B) was developed during the Plutonium Immobilization Program (PIP) to immobilize plutonium. A limited amount of performance testing was performed on this baseline composition before efforts to further pursue Pu disposition via a glass waste form ceased. Therefore, the objectives of this present task were to fabricate plutonium loaded LaBS Frit B glass and perform additional testing to provide near-term data that will increase confidence that LaBS glass product is suitable for disposal in the Yucca Mountain Repository. Specifically, testing was conducted in an effort to provide data to Yucca Mountain Project (YMP) personnel for use in performance assessment calculations.

Plutonium containing LaBS glass with the Frit $\mathrm{B}$ composition with a $9.5 \mathrm{wt} \% \mathrm{PuO}_{2}$ loading was prepared for testing. Glass was prepared to support Product Consistency Testing (PCT) at Savannah River National Laboratory (SRNL) and for additional performance testing at Argonne National Laboratory (ANL) and Pacific Northwest National Laboratory (PNNL). The glass was characterized using $\mathrm{x}$-ray diffraction (XRD) and scanning electron microscopy coupled with energy dispersive spectroscopy (SEM/EDS) prior to performance testing. A series of PCTs were conducted at SRNL with varying exposed surface area and test durations. The leachates from these tests were analyzed to determine the dissolved concentrations of key elements. Acid stripping of leach vessels was performed to determine the concentration of the glass constituents that may have sorbed on the vessels during leach testing. Additionally, the leachate solutions were ultrafiltered to quantify colloid formation. The leached solids from select PCTs were examined in an attempt to evaluate the Pu and neutron absorber release behavior from the glass and to identify the formation of alteration phases on the glass surface.

Characterization of the glass prior to testing revealed that some undissolved plutonium oxide was present in the glass. The undissolved particles had a disk-like morphology and likely formed via coarsening of particles in areas compositionally enriched in plutonium. Similar disk-like $\mathrm{PuO}_{2}$ phases were observed in previous LaBS glass testing at PNNL. In that work, researchers concluded that plutonium formed with this morphology as a result of the leaching process. It was more likely that the presence of the plutonium oxide crystals in the PNNL testing was a result of glass fabrication.

A series of PCTs were conducted at $90^{\circ} \mathrm{C}$ in ASTM Type 1 water. The PCT - Method A (PCT-A) was conducted to compare the Pu LaBS Frit B glass durability to current requirements for High Level Waste (HLW) glass in a geologic repository. The PCT-A test has a strict protocol and is designed to specifically be used to evaluate whether the chemical durability and elemental release characteristics of a nuclear waste glass have been consistently controlled during production and, thus, meet the repository acceptance requirements. The PCT-A results on the Pu containing LaBS Frit B glass showed that the glass was very durable with a normalized elemental release value for boron of approximately $0.02 \mathrm{~g} / \mathrm{L}$. This boron release value was better than two orders of magnitude better from a boron release standpoint than the current Environmental Assessment (EA) glass used for repository acceptance. The boron release value for EA glass is $16.7 \mathrm{~g} / \mathrm{L}$. 
The PCT- Method B (PCT-B) allows for more flexibility in testing. The flexibility includes the ability to: test in different leach vessels; test at different glass surface area to leachate volume ratios; test at different temperatures; and test at different times. Four different PCT-B tests were applied to the Pu LaBS glass.

- $\quad$ PCT-A-like condition test in a Teflon ${ }^{\circledR}$ vessel instead of stainless steel at a leachate to glass ratio of 10:1 for a seven-day duration. This test was performed to test the effect of vessel material vs. the PCT-A results.

- $\quad$ PCT-A-like condition test in Teflon ${ }^{\circledR}$ vessel instead of stainless steel at a leachate to glass ratio of 10:1 for a fourteen-day duration. This test was performed to test the effect of a longer duration and vessel material on the results.

- Triplicate tests in steel vessels for seven day duration at slightly lower water to glass ratios than the PCT-A test. These were performed to test the effect of two different ratios of leachant volume to surface area of the glass on the results.

- Tests in Teflon ${ }^{\circledR}$ vessels for periods of longer than the seven days at $90^{\circ} \mathrm{C}$. In addition to seven days periods of 14,28 , and 56 days were chosen. These PCT-B tests used much higher $\mathrm{SA} / \mathrm{V}$ ratios of $21,000 \mathrm{~m}^{-1}$.

The PCT-B elemental release rates were similar to the elemental release values from PCT-A testing. This further indicated that the LaBS Frit B glass is very durable as measured by the PCT.

All of the PCT leachates in this study were first filtered through prototypical $0.45 \mu \mathrm{m}$ syringe filters. In addition, all but one of the $\mathrm{Pu}$ glass leachates were also filtered through micro filters to assess whether colloids formed during the leaching. Comparison of the initial syringe-filtered leachates to the ultrafiltered leachates indicated that normalized plutonium releases were essentially the same within the analytical uncertainty of the ICP-MS methods used to quantify plutonium in the leachates. These results indicated that colloidal plutonium species do not form under the PCT conditions used in this study.

Several items were identified in this testing where further analysis and testing are needed. PCT-B testing should be conducted for longer durations (as planned) on the Frit B composition and other candidate compositions to provide additional insight into colloid and alteration phase formation. Due to discrepancies in the preliminary Pu Frit B radioactive glass composition analytical data, the normalized release data provided in this report were based on targeted glass composition values. Although, it is expected to only have a minor impact on the calculations (the current analytical data set shows that no glass constituent varies from the targeted value by more than $30 \%$ and most varied by less than 10\%), the glass compositional data should be finalized to complete the data set. The vessel strip data obtained in this testing was not used in the elemental release calculations. The results obtained indicated that plutonium did not appear to be preferentially sorbed on the leach vessel surfaces. However, due to the extremely low release values for this glass, the actual contribution of sorption to the glass release values could not be quantified. Improved vessel cleaning and strip methods need to be investigated if strip data is deemed important for future testing. 


\section{TABLE OF CONTENTS}

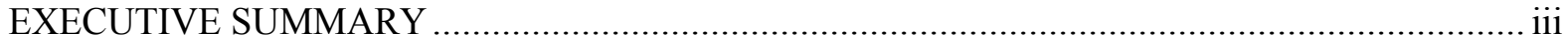

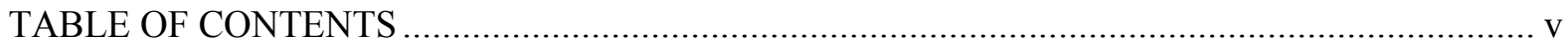

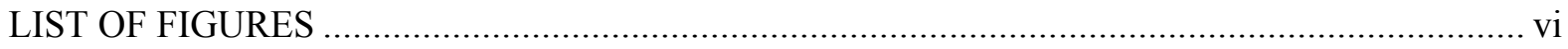

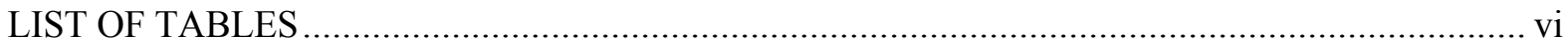

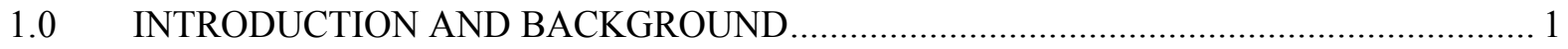

1.1 Previous Product Consistency Testing with LaBS Glass ……………………………..... 3

1.1.1 Glass Formulations .............................................................................................. 3

1.1.2 PCT testing on Pu LaBS Glass ....................................................................... 4

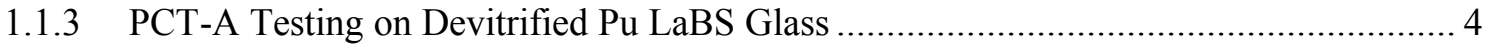

1.1.4 PCT-A Testing on LaBS Glass with Impurities......................................................... 5

$2.0 \quad$ APPROACH

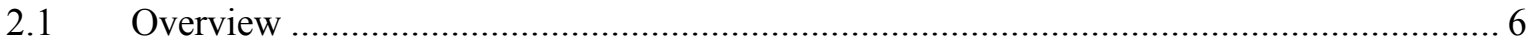

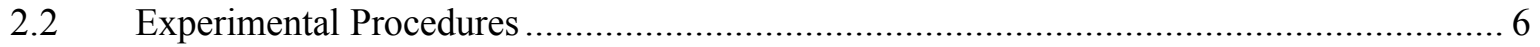

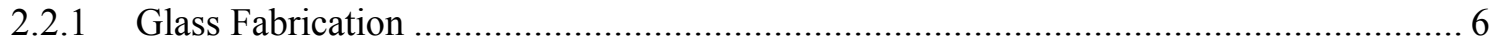

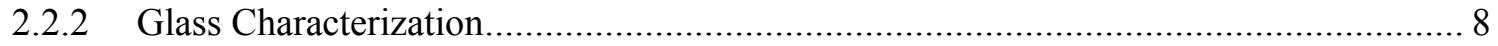

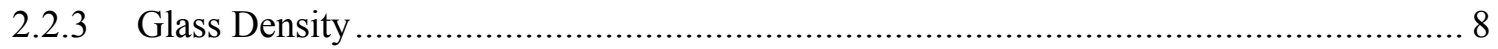

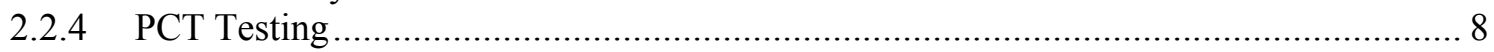

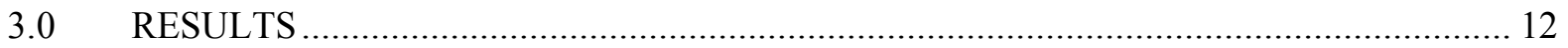

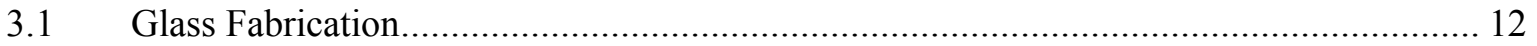

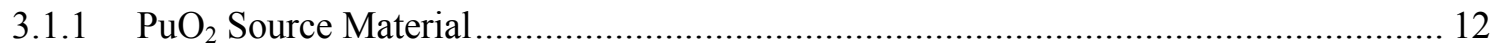

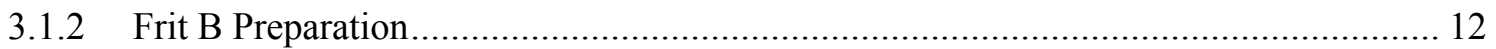

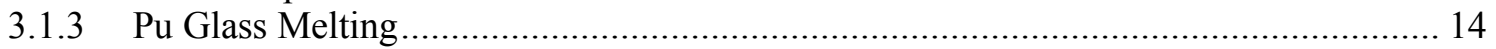

3.2 Characterization of Pu LaBS Frit B Glass ……………........................................... 14

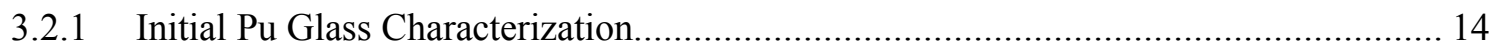

3.2.2 Microstructural Analysis of $\mathrm{PuO}_{2}$ Source Material............................................... 18

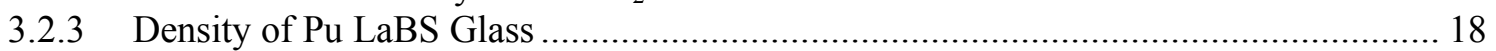

3.2.4 Chemical Analysis of Pu Frit B LaBS Glass ............................................................. 19

3.3 Results of PCT-A and PCT-B Tests on Pu Frit B Glass............................................. 21

3.3.1 Comparison of Normalized Releases of Pu Glass and EA Glass in PCT-A.................. 23

3.3.2 Examination of Leached PCT-A Pu Glass by SEM …………………………........ 25

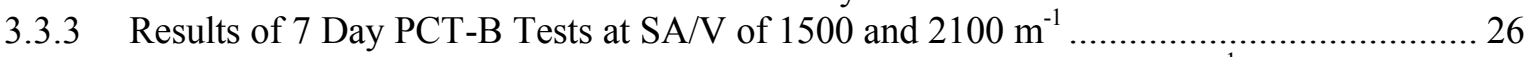

3.3.4 Results of 7 and 14 Day PCT-B Tests at SA/V of 1500 and $21000 \mathrm{~m}^{-1} \ldots \ldots \ldots \ldots \ldots \ldots \ldots \ldots . .27$

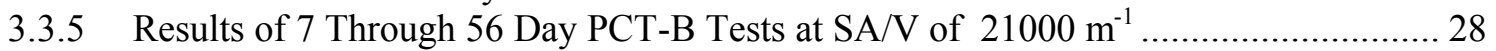

3.3.6 Results of Filtered vs. Ultrafiltered PCT-A and PCT-B Tests.................................... 28

3.3.7 Examination of PCT-B Leached Pu Glass After 28 and 56 Days................................ 31

3.3.8 Acid-Stripping of PCT Vessels............................................................................. 32

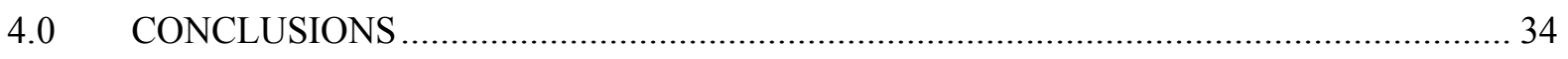

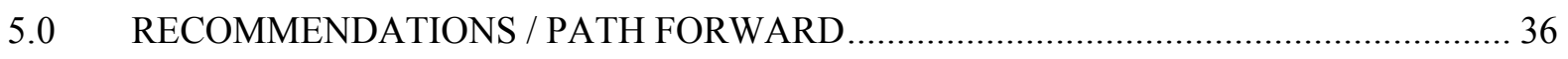

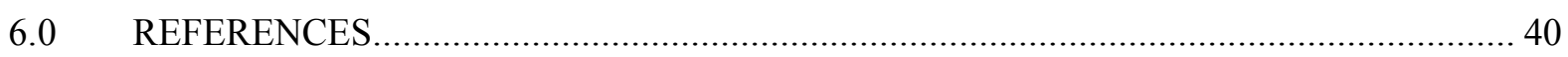




\section{LIST OF FIGURES}

Figure 1. Photograph of $\mathrm{Pu}$ LaBS Frit B glass to be used for performance testing. ....................... 14

Figure 2. XRD patterns of Pu LaBS glass shard samples..................................................... 15

Figure 3. SEM micrograph and corresponding EDS spectrum showing a $\mathrm{PuO}_{2}$ crystal in the $\mathrm{Pu}$

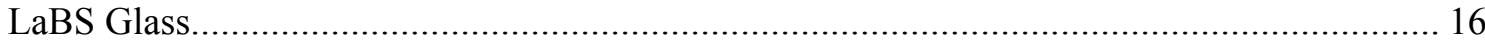

Figure 4. XRD pattern of $\mathrm{Pu}$ LaBS glass ground, sieved, and washed sample indicating presence of undissolved $\mathrm{PuO}_{2}$

Figure 5. SEM micrographs and corresponding EDS spectra showing undissolved $\mathrm{PuO}_{2}$ crystals

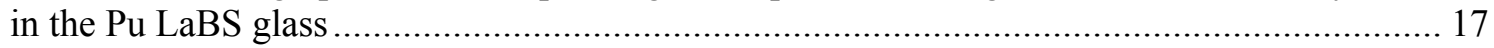

Figure 6. SEM micrographs of $\mathrm{PuO}_{2}$ source material showing the fine crystallite size of the starting material....

Figure 7. SEM micrographs and corresponding EDS spectra of leached Pu LaBS glass showing undissolved $\mathrm{PuO}_{2}$ crystals but no alteration phase formation ............................................ 25

Figure 8. SEM micrographs of 28 and 56 day leached Pu LaBS glass showing undissolved $\mathrm{PuO}_{2}$ crystals but no alteration phase formation.

\section{LIST OF TABLES}

Table 1. LaBS Glass Compositions used in Previous Testing ................................................... 3

Table 2. Normalized Elemental Releases for PCT with LaBS Frit A Glass ${ }^{6}$.................................. 4

Table 3. Normalized Elemental Releases for PCT with Amorphous and Devitrified LaBS Frit A Glasses $^{7}$

Table 4. Normalized Elemental Releases for PCT with Impurity LaBS Frit B Glass Compositions ${ }^{8}$

Table 5. Impurity Concentrations in $\mathrm{PuO}_{2}$ Source Material ................................................... 13

Table 6. Measured (Average of Duplicate Measurements) vs. Targeted Composition for Frit B

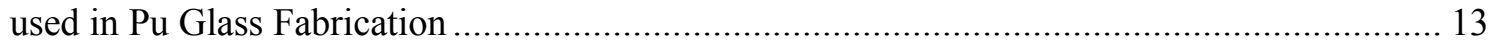

Table 7. Measured vs. Targeted Wt\% Composition for Pu Frit B Surrogate Glass......................... 20

Table 8. Summary of PCT-A and PCT-B Tests Performed on Pu Frit B LaBS Glass.................... 22

Table 9. Average Concentrations (ppm) of B, Si, $\mathrm{Li}$ and $\mathrm{Na}$, and the Final $\mathrm{pH}$ from the $90{ }^{\circ} \mathrm{C}$ PCT Based on Triplicate PCT-A Tests and Blanks

Table 10. Average Normalized (Grams Glass/L) PCT-A Results for Pu FRIT B and EA Glass Based on Triplicate Tests.

Table 11. Average Normalized Releases (Grams Glass $/ \mathrm{m}^{2}$ ) in PCT Tests at SA/V Ratios of 1500 and $2100 \mathrm{~m}^{-1}$ in Steel Vessels ${ }^{\mathrm{a}}$....

Table 12. Average Normalized Releases (Grams Glass $/ \mathrm{m}^{2}$ ) in PCT-B Tests at SA/V Ratios of 1500 and $21000 \mathrm{~m}^{-1}$ in Teflon Vessels.

Table 13. Average Normalized Releases (Grams Glass $/ \mathrm{m}^{2}$ ) in PCT-A Tests at SA/V Ratios of 1500 - Steel and Teflon ${ }^{\circledR}$

Table 14. Average Normalized Releases (Grams Glass $/ \mathrm{m}^{2}$ ) in PCT Tests at SA/V Ratio of $21000 \mathrm{~m}^{-1}$ in Teflon Vessels from 7 to 56 Days....

Table 15. Average Normalized Releases (Grams Glass $/ \mathrm{m}^{2}$ ) in PCT-A and PCT-B Tests Comparing Filtered vs. Ultrafiltered. 


\subsection{INTRODUCTION AND BACKGROUND}

The Department of Energy Office of Environmental Management (DOE/EM) plans to conduct the Plutonium Disposition Project at the Savannah River Site (SRS) to disposition excess weapons-usable plutonium. Vitrification appears to be a viable option for the disposition of the plutonium. An important part of the vitrification approach is to reduce the attractiveness of the plutonium by fabricating a plutonium glass form and immobilizing the Pu form within the high level waste (HLW) glass prepared in the Defense Waste Processing Facility (DWPF). This requires that the Pu Disposition Project schedule is consistent with EM plans for immobilizing HLW in the DWPF. Therefore, several inputs are needed to provide confidence that the Pu Disposition Project will meet the project schedule. Key inputs are nearterm data that will increase confidence that lanthanide borosilicate (LaBS) glass product is suitable for disposal in the Yucca Mountain Repository.

A workshop was held on April 28, 2005 at the Bechtel SAIC Company facility in Las Vegas, NV to define the near term data needs. Dissolution rate data and the fate of plutonium oxide and the neutron absorbers during the dissolution process were defined as key data needs. A suite of short-term tests were defined at the workshop to obtain the needed data. The objectives of these short-term tests are to obtain data that can be used to show that the dissolution rate of a LaBS glass is acceptable and to demonstrate that the extent of $\mathrm{Pu}$ separation from neutron absorbers, as the glass degrades and dissolves, is not likely to lead to criticality concerns. An additional data need was identified regarding the degree of macroscopic cracking that occurs during processing of the Pu glass waste form and subsequent pouring of HLW glass in the DWPF. A final need to evaluate new frit formulations that may increase the durability of the plutonium glass and/or decrease the degree to which neutron absorbers separate from the plutonium during dissolution was also identified. This report covers testing to support the near term data need regarding glass dissolution performance on the current baseline Frit B composition. Other data needs will be documented elsewhere.

The Product Consistency Test (PCT) was identified as a means to provide some of the near term performance data. The PCT is a static test method in which known masses of crushed glass and ASTM Type 1 purified water are reacted for a desired duration. ${ }^{1}$ The PCT Method A test is conducted under specific test conditions: $90^{\circ} \mathrm{C}$; 7 days; $-100+200$ mesh-size glass; water/glass mass ratio of 10 . The PCT Method $\mathrm{B}$ allows for varying the test conditions (temperature, duration, and glass/water mass ratio are commonly varied). Under PCT conditions, components that are released from the glass as it dissolves accumulate in the solution throughout the test and affect the degradation rate through solution feedback effects. The primary feedback effects are through the effects of dissolved silica and increased $\mathrm{pH}$. The extent of degradation under these tests conditions can be compared with that of other waste forms.

There were two reasons to perform the PCT. The first was that the results are used as a measure of acceptance in the Waste Acceptance Product Specifications Document (WAPS). ${ }^{2}$ The WAPS provides the repository acceptance requirements for vitrified HLW glass. A current acceptance criterion is that the PCT Method A response must be less than the response of the Environmental Assessment (EA) benchmark glass, after normalizing the glass compositions. The average rate in the PCT Method A test, based on the amount of boron released over 7 days, is used to determine the maximum rate calculated by the HLW glass degradation model in alkaline solutions. The standard 7-day PCT in demineralized water (PCT-A) was conducted in this task to demonstrate compliance with the waste acceptance criterion and determine the value of the $\mathrm{k}_{\mathrm{E}}$ rate parameter for comparison with the Defense HLW Glass Degradation Model $^{3}$ The second reason for utilizing the PCT was the need for long-term static test results that can be used to verify the applicability of the degradation model. Thus, a primary focus of this effort was in the 
WSRC-TR-2006-00033

Revision 0

use of the PCT Method B (PCT-B) to study the formation and stability of colloids and to study alteration phases formed on the glass surface. 


\subsection{Previous Product Consistency Testing with LaBS Glass}

\subsubsection{Glass Formulations}

Glass formulation development was conducted at the Savannah River Technology Center (SRTC) (now the Savannah River National Laboratory (SRNL)) in support of the Plutonium Immobilization Program (PIP). ${ }^{4,5}$ Two frit compositions were developed for LaBS glass. Frit A employed only gadolinium as a neutron absorber, whereas Frit B used both gadolinium and hafnium as neutron absorbers. (Hafnium replaced zirconium in the frit composition.) Boron is not relied upon as a neutron absorber because it is released from the waste form faster than plutonium and can become separated from plutonium as the waste form degrades. The chemistries of gadolinium and hafnium are similar to that of plutonium, and these elements are expected to be released at similar rates as the LaBS glass corrodes. Both frits were used to make LaBS glasses for testing, however, the majority of previous performance testing was conducted with the Frit A composition. Due to the additional neutron absorbers present in the Frit B formulation, this frit became the reference composition at the culmination of PIP glass testing. Table 1 shows the relative compositions of Frit A and Frit B.

Table 1. LaBS Glass Compositions used in Previous Testing

\begin{tabular}{|c|c|c|}
\hline & Frit A & Frit B \\
\hline Oxide & Mass \% & Mass \% \\
\hline $\mathbf{A l}_{2} \mathbf{O}_{3}$ & 21.5 & 21.3 \\
\hline $\mathbf{B}_{\mathbf{2}} \mathbf{O}_{3}$ & 11.7 & 11.6 \\
\hline $\mathbf{G d}_{\mathbf{2}} \mathbf{O}_{3}$ & 8.6 & 12.8 \\
\hline $\mathbf{H f O}_{\mathbf{2}}$ & -- & 6.6 \\
\hline $\mathbf{L a}_{2} \mathbf{O}_{3}$ & 12.4 & 8.1 \\
\hline $\mathbf{N d}_{\mathbf{2}} \mathbf{O}_{3}$ & 12.8 & 8.2 \\
\hline $\mathbf{S i O}_{\mathbf{2}}$ & 29.2 & 28.9 \\
\hline $\mathbf{S r O}$ & 2.5 & 2.5 \\
\hline $\mathbf{Z r O}_{\mathbf{2}}$ & 1.3 & -- \\
\hline
\end{tabular}




\subsubsection{PCT testing on Pu LaBS Glass}

PCT Method B tests were conducted at Argonne National Laboratory (ANL) using the Frit A composition with a 11.9 wt $\% \mathrm{PuO}_{2}$ loading. ${ }^{6}$ Product Consistency Tests were conducted at $90^{\circ} \mathrm{C}$ at various SA/V ratios. Since the density of LaBS glass is considerably higher than typical borosilicate HLW glasses, the water/glass mass ratio was adjusted to give the desired SA/V ratio. Seven day PCT-B tests were conducted on glass with an SA/V of about $2000 \mathrm{~m}^{-1}$. Other PCT Method B tests were conducted for longer durations at a water/glass mass ratio to achieve an $\mathrm{S} / \mathrm{V}$ ratio of $\sim 20,000 \mathrm{~m}^{-1}$. In these tests, the vessels were acid stripped. Leachates and vessel strip solutions were analyzed from these PCTs and the test results are summarized in Table 2.

Table 2. Normalized Elemental Releases for PCT with LaBS Frit A Glass ${ }^{6}$

\begin{tabular}{|c|c|c|c|c|c|c|}
\hline \multirow{2}{*}{ Test No. } & \multirow{2}{*}{ SA/V, $\mathbf{m}^{-\mathbf{1}}$} & \multirow{2}{*}{ Duration, $\mathbf{d}$} & \multicolumn{4}{|c|}{ Normalized Mass Loss, $\mathbf{g} / \mathbf{m}^{\mathbf{2}}$} \\
\cline { 4 - 7 } & & & $\mathbf{B}$ & $\mathbf{S i}$ & $\mathbf{P u}$ & $\mathbf{G d}$ \\
\hline 1 & 2080 & 7 & 0.060 & 0.026 & 0.010 & 0.003 \\
\hline 2 & 1950 & 7 & 0.077 & 0.024 & 0.009 & 0.003 \\
\hline 3 & 19800 & 28 & 0.048 & 0.017 & 0.013 & 0.014 \\
\hline 4 & 19500 & 98 & 0.072 & 0.025 & 0.010 & 0.016 \\
\hline 5 & 19700 & 182 & 0.068 & 0.020 & 0.0084 & 0.0072 \\
\hline
\end{tabular}

It should be noted that the values of $\mathrm{NL}(\mathrm{B})$ were higher than the values of $\mathrm{NL}(\mathrm{Si}), \mathrm{NL}(\mathrm{Pu})$, and $\mathrm{NL}(\mathrm{Gd})$ in all tests. This indicated that the degradation rate of the glass matrix, as indicated by the release of B, bounded the releases of $\mathrm{Si}, \mathrm{Pu}$, and $\mathrm{Gd}$.

\subsubsection{PCT-A Testing on Devitrified Pu LaBS Glass}

Testing to evaluate the effect of glass devitrification was conducted at SRTC using the Frit A composition with a $9 \mathrm{wt} \% \mathrm{PuO}_{2}$ loading. ${ }^{7}$ Crystallization in the LaBS glass was induced by reheating a quenched glass to $990^{\circ} \mathrm{C}$ over 2 hours then slow cooling (about $1^{\circ} \mathrm{C}$ /minute). Crystallites of $\mathrm{PuO}_{2}$ were detected with XRD and observed to be uniformly distributed throughout the sample with SEM. Seven-day PCTs (Method A) were conducted with samples of both homogeneous (amorphous) and devitrified LaBS glasses. The results for the analyzed leachates are summarized in Table 3. Note: the normalized leachate concentration values in Table 3 are reported using the conventional units $\mathrm{g} / \mathrm{L}$ since the tests were conducted at the reference volume of solution to mass of glass ratio of 10:1 (as opposed to the $\mathrm{g} / \mathrm{m}^{2}$ units in Table 2). It must also be noted that these results are not directly comparable to the results in Table 2 because these tests were conducted at a water/glass mass ratio of 10. These results also only include filtered leachate data and no acid strip solution contribution to the normalized releases. Devitrification did not affect the release of $\mathrm{B}, \mathrm{Si}$, or $\mathrm{Sr}$, but did result in a decrease in the release of $\mathrm{Pu}$. A lower release of $\mathrm{Pu}$ in the devitrified material was also observed in 45-day PCT-B tests. It was postulated that lower Pu release rate resulted from a lowering of the $\mathrm{PuO}_{2}$ in the matrix glass by the formation of $\mathrm{PuO}_{2}$ crystallites with the $\mathrm{PuO}_{2}$ precipitates being more durable than the glass. 
Table 3. Normalized Elemental Releases for PCT with Amorphous and Devitrified LaBS Frit A Glasses ${ }^{7}$

\begin{tabular}{|c|c|c|c|c|}
\hline \multirow{2}{*}{} & \multicolumn{4}{|c|}{ Normalized Concentration, g/L } \\
\cline { 2 - 5 } & $\mathbf{B}$ & $\mathbf{S i}$ & $\mathbf{S r}$ & $\mathbf{P u}$ \\
\hline Amorphous & 0.026 & 0.019 & 0.027 & 0.017 \\
\hline Devitrified & 0.029 & 0.020 & 0.030 & 0.0036 \\
\hline
\end{tabular}

\subsubsection{PCT-A Testing on LaBS Glass with Impurities}

The effect of impurities in the waste stream on the durability of the LaBS glass was measured using a 7-day PCT (Method A) with glasses made with Pu and $\mathrm{U}$ and with $\mathrm{Pu}$ and a mixture of impurities. ${ }^{8}$ This testing was conducted with the LaBS Frit $\mathrm{B}$ composition. In addition to uranium, the predominant impurities in the surplus plutonium include $\mathrm{B}$ (0.13), $\mathrm{Ba}, \mathrm{Ca}, \mathrm{Cl}(1.7), \mathrm{Cr}(0.11), \mathrm{F}(0.45), \mathrm{Fe}(0.45)$, $\mathrm{Ga}$ (1.1), K, Mg, Mo (0.45), Na (0.45), Ni (0.32), rare earth elements, Si (0.85), Ta (0.65), W (1.7), Zn (0.10), and Zr. The numbers in parentheses following some elements are the maximum expected mass \% of that element in the plutonium feeds. Based on these maximum impurity levels an "impurity mix" was developed to facilitate testing. The $\mathrm{Pu}$ /impurity mixture glass included a loading of $6.6 \mathrm{wt} \% \mathrm{PuO}_{2}$ in the glass and a loading of $7.4 \mathrm{wt} \%$ of the impurity mix. The $\mathrm{Pu} / \mathrm{U}$ glass included loadings of 9.0 and 6.0 for $\mathrm{PuO}_{2}$ and $\mathrm{UO}_{3}$, respectively. The PCT results from filtered leachate analyses for the impurity glasses are shown in Table 4. Note: the normalized leachate concentration values in Table 4 are reported using the conventional units $\mathrm{g} / \mathrm{L}$ since the tests were conducted at the reference volume of solution to mass of glass ratio of 10:1 (as opposed to the $\mathrm{g} / \mathrm{m}^{2}$ units in Table 2). Again it must be noted that these results should not be compared to the results in Table 2 because these tests were conducted at a water/glass mass ratio of 10 and with no acid strip solution data contributions.

Table 4. Normalized Elemental Releases for PCT with Impurity LaBS Frit B Glass Compositions ${ }^{8}$

\begin{tabular}{|l|c|c|c|c|c|c|}
\hline & \multicolumn{6}{|c|}{ Normalized Concentration, g/L } \\
\cline { 2 - 7 } & $\mathbf{B}$ & $\mathbf{L a}$ & $\mathbf{N d}$ & $\mathbf{S i}$ & $\mathbf{S r}$ & $\mathbf{P u}$ \\
\hline $\mathbf{P u} / \mathbf{U}$ & 0.020 & 0.0012 & 0.00024 & 0.016 & 0.021 & 0.0044 \\
\hline $\mathbf{P u} / \mathbf{I m p u r e}$ & 0.014 & 0.0018 & 0.00068 & 0.013 & 0.017 & 0.0035 \\
\hline
\end{tabular}




\subsection{APPROACH}

\subsection{Overview}

Previous performance testing on LaBS glass was predominantly preformed on the Frit A composition. The objectives of this task were to prepare Pu loaded LaBS glass with a $9.5 \mathrm{wt} \% \mathrm{PuO}_{2}$ loading (using the current reference Frit B composition) for testing, perform PCTs under varying conditions, and analyze the leachates and solids from the PCTs. Plutonium containing LaBS glass with the Frit B composition (Table 1) was prepared at the SRNL for testing. A series of PCTs were conducted with varying exposed surface area and test durations. The leachates from these tests were analyzed to determine the dissolved concentrations of key elements. Additionally, the leachate solutions were ultrafiltered to quantify colloid formation. The PCT vessels were also acid stripped and the strip solution analyzed to more accurately quantify the dissolved element concentrations. The leached solids from select PCTs were examined in an attempt to evaluate the $\mathrm{Pu}$ and neutron absorber release behavior from the glass and to identify the formation of alteration phases on the glass surface.

\subsection{Experimental Procedures}

\subsubsection{Glass Fabrication}

Plutonium glass was fabricated for testing at SRNL, ANL and PNNL. To facilitate fabrication of the radioactive glass Frit B glass, frit was first prepared in a non-radioactive environment. The frit was prepared by mixing reagent grade chemicals in the proportion given in Table 1 scaled to produce a $300 \mathrm{~g}$ batch of frit. Oxides chemicals were used for all components except for boron. Boric acid was used to provide the necessary $\mathrm{B}_{2} \mathrm{O}_{3}$ content in the frit. The frit batch was melted at $1500^{\circ} \mathrm{C}$ in $\mathrm{Pt} / \mathrm{Rh}$ crucibles. After nominally two hours at temperature, the crucible was removed from the furnace at temperature and the molten glass poured on a steel plate. The "cullet" pieces were collected for subsequent grinding. The cullet was ground in an automated agate milled and sieved to collect the fraction that was -325 mesh $(<45 \mu \mathrm{m})$. Two batches of Frit B were prepared using this method.

After the frit was melted and ground, samples from both batches were analyzed using Inductively Coupled Plasma - Atomic Emission Spectroscopy (ICP-AES) to verify the composition. The frit samples were prepared in duplicate using a sodium peroxide/sodium hydroxide $\left(\mathrm{Na}_{2} \mathrm{O}_{2} / \mathrm{NaOH}\right)$ fusion with a $\mathrm{HCl}$ uptake. The peroxide fusion dissolution allows for the analysis of all elemental concentrations of interest (Al, B, Gd, Hf, La, Nd, Si, and Sr). The resulting solutions were analyzed in duplicate using the ICPAES.

The plutonium oxide material was obtained from personnel in the Actinide Technology Section of SRNL. The material was produced at the Savannah River Site (SRS) and was obtained from a standard that was previously used for calorimetry testing. Before using the $\mathrm{PuO}_{2}$ to fabricate glass, the isotopic content and purity of the material were determined. A sample of the $\mathrm{PuO}_{2}$ was dissolved in a mixture of $8 \mathrm{M}$ $\mathrm{HNO}_{3} / 0.05 \mathrm{M} \mathrm{KF}$ to facilitate the analyses. Gamma scan and liquid scintillation counting were used to determine the actinide isotopic distribution. To assess for the presence of any impurities, ICP-AES was utilized. 
Once the composition of the frit was verified via chemical analysis, the frit was weighed into the appropriate amount to produce a nominal $100 \mathrm{~g}$ of glass with a $9.5 \mathrm{wt} \% \mathrm{PuO}_{2}$ loading. The frit was placed in a plastic bottle for introduction into the SRNL Shielded Cells facility. In the Shielded Cells, the appropriate quantity of $\mathrm{PuO}_{2}$ was weighed and added to the bottle containing the frit. The bottle was capped and the mixture manually mixed for a few minutes using the rotation afforded by the manipulator arm. The mixture of frit and $\mathrm{PuO}_{2}$ was placed in a Pt/Rh crucible for melting.

The $\mathrm{Pt} / \mathrm{Rh}$ crucible was placed in a high temperature elevator furnace and the furnace was ramped to the melting temperature of $1500^{\circ} \mathrm{C}$ using a ramp rate of $10^{\circ} \mathrm{C} /$ minute. The melt was held at temperature for 4 hours and promptly removed from the furnace and quenched in a pan of water. Upon cooling, the glass was manually removed from the crucible by "hammering" the crucible. In this manner nominally $99 \%$ of the glass was recovered from the crucible. A total of four $100 \mathrm{~g}$ batches of plutonium loaded glass were fabricated in this manner.

In an effort to enhance homogenization of the glass, the glass was melted a second time. To provide glass for performance testing at SRNL and PNNL, a large batch of $300 \mathrm{~g}$ of glass was re-melted (the $300 \mathrm{~g}$ batch was comprised of three of the initial $100 \mathrm{~g}$ batches). The glass was melted using the methodology described above. Because performance testing at SRNL and PNNL was to be conducted on ground and sized glass particles, the glass "cullet" resulting from manually removing the glass from the crucibles was adequate. It was necessary to provide a "bar" geometry glass sample to ANL since the testing being conducted at that laboratory utilizes monolithic "wafer" samples. Platinum/rhodium "boats" were prepared by folding $\mathrm{Pt} / \mathrm{Rh}$ sheet to produce a mold for the glass bars.

A first attempt to produce the bars involved adding cullet material directly to the boat (stabilized in a hollowed-out refractory brick) and melting in the boat at $1500^{\circ} \mathrm{C}$. This method was initially selected because it minimized handling in the shielded cell. After nominally two hours at temperature, the furnace was rapidly cooled by slightly opening the furnace door. Once a temperature of $700^{\circ} \mathrm{C}$ was achieved, the furnace was held at this temperature for approximately 1.5 hours to anneal the glass bar. The furnace was turned off and the sample was allowed to cool in the furnace. Upon removal of the $\mathrm{Pt} / \mathrm{Rh}$ boat from the furnace, it was evident that some glass had leaked from the boat into the brick. There was, however, approximately $60 \%$ of the glass remaining in the boat that was in bar form and deemed suitable for testing at ANL. The bar was removed in pieces by manually forcing from the boat.

A second attempt to make glass in a bar form was done in a more conventional manner and proved to be more successful. In this instance, the glass cullet was melted in a $\mathrm{Pt} / \mathrm{Rh}$ crucible for 4 hours and removed from the furnace at temperature. The molten glass was then poured in the $\mathrm{Pt} / \mathrm{Rh}$ boat and the boat placed in the furnace for annealing at $700^{\circ} \mathrm{C}$. The glass was annealed for about 1.5 hours. The furnace was then turned off and the sample was allowed to cool in the furnace. Upon removal from the furnace, the glass bar was readily removed from the $\mathrm{Pt} / \mathrm{Rh}$ boat by simply inverting the boat. Both bar samples were sent to ANL for characterization and subsequent testing.

\footnotetext{
${ }^{a}$ Due to issues with shipping plutonium containing glass to Washington State, no glass has been shipped to PNNL for testing as of the date of this report.
} 


\subsubsection{Glass Characterization}

Samples of the Pu glass were initially characterized to provide confidence that the glass was of acceptable quality to proceed with leach testing. X-ray diffraction (XRD) and SEM/EDS were used for this assessment. Specifically, the analyses were used to examine for the presence of crystalline species (e.g. undissolved $\mathrm{PuO}_{2}$ ) and other heterogeneities in the glass. Analyses were initially conducted on shard samples.

To conduct the PCT, a glass is ground, sieved and washed. This provides a material with a consistent surface area that is free of fines for subsequent leach testing. It also would provide a significant amount of material surface area for physical examination. Therefore, a portion of the ground Pu LaBS Frit B glass before and after leaching was analyzed by SEM. To facilitate examination in the SEM, the ground glass samples were placed on an aluminum stub.

\subsubsection{Glass Density}

The density of the glass was measured in duplicate by a water displacement method using a $50 \mathrm{~mL}$ pycnometer with a built in thermometer. The glass fraction that corresponded to the $>100$ mesh fraction from the PCT glass preparation, was used for the density measurements. The pycnometer was calibrated with ASTM Type 1 water prior to use. The density of the glass was necessary to calculate the mass of glass to be used in the PCTs to ensure that the specified surface area was used in the testing. Since the density of the Pu LaBS glass is nominally $30-40 \%$ higher than a typical borosilicate HLW glass, it is necessary to utilize a greater mass of Pu LaBS glass to achieve a comparative glass surface area to HLW glass.

\subsubsection{PCT Testing}

The PCT is an ASTM Standard Test (ASTM 1285 - 02) for leaching nuclear waste forms. With regard to glass it is a crushed glass static leach test performed in sealed vessels at $90^{\circ} \mathrm{C}$ using ASTM Type 1 water. The ASTM Type 1 water was prepared using a Barnstead Nanopure Infinity ${ }^{\mathrm{TM}}$ ultrapure water system capable of filtering the water to at least $18 \mathrm{Mohm} \mathrm{cm}$. Two types of PCTs were used to evaluate the durability of the Pu LaBS glass prepared with Frit B. One was the PCT-A test and the other, PCT-B.

The PCT-A test has a strict protocol and was designed to specifically be used to evaluate whether the chemical durability and elemental release characteristics of a nuclear waste glass have been consistently controlled during production. The test, which is performed in stainless steel vessels with $10.0 \pm 0.5 \mathrm{~mL}$ of ASTM water per gram of glass, includes appropriate blanks and standards (EA glass and the Approved Reference Material - 1 (ARM-1) glass) as prescribed by the ASTM procedure. The PCT-A test was applied to triplicate samples of the Pu LaBS Frit B glass. 
The PCT-B allows the researcher more flexibility. Four different PCT-B tests were applied to the Pu LaBS glass with all tests conducted at $90^{\circ} \mathrm{C}$ using ASTM Type 1 water. These are listed below:

- $\quad$ PCT-A tests in Teflon ${ }^{\circledR}$ vessels instead of stainless steel. There were performed to test the effect of vessel material on the results.

- Tests in steel vessels at a slightly differently water to glass ratios than the PCT-A test. There were performed to test the effect of two different ratios of leachant volume to surface area of the glass on the results.

- Tests in Teflon ${ }^{\circledR}$ vessels for periods of longer than the seven days at $90^{\circ} \mathrm{C}$. In addition to seven days periods of 14,28 , and 56 days were chosen.

- For all but one of the PCT tests the leachates were filtered through micro filters to assess whether colloids formed during the leaching a $90^{\circ} \mathrm{C}$. This filtering referred to as 'ultrafiltration' used high-flow Biomax-PB polyether sulfone membrane filters that are 30,000 nominal molecular weight limit (NMWL). These filters are listed as 'Ultrafree-CL Centriugal Filter Units' from Millipore Corp. This ultrafiltration requires a centrifuge to force the leachate through the filter. The protocol for the PCT-A allows the use of only a $45 \mu \mathrm{m}$ filter. Nalgene ${ }^{\circledR} 0.45 \mu \mathrm{m}$ syringe filters (25-mm surfactant free cellulose acetate membrane) were used with 20 -mL latex-free Luer-LOK ${ }^{\mathrm{TM}}$ syringes in the PCT-A.

Ultrafiltration of the Pu glass leachates for this study used the Millipore ultrafilters described above in a Thermo IEC Centra CL2 centrifuge unit that was fit with a \#221 rotor. This rotor is a 6-place fixed trunniun swinging bucket design with nominal 3500 RPM maximum speed capability. The ultrafilters were pre-wetted with ASTM Type 1 water. Pre-wetting involved adding $\sim 2 \mathrm{~g}$ of water to the filter and centrifuging for 5 minutes on the maximum RPM setting. This typically pre-wetted the filter with $<0.03$ $\mathrm{g}$ of water. The pre-wetted ultrafilters were then wetted with some of the Pu glass syringe-filtered leachates from the initial 1,500 and 2,000 $\mathrm{m}^{-1} \mathrm{PCTs}$, followed by another 5 minutes of centrifuging. These ultrafiltered PCT leachates were analyzed by ICP-MS. The objective of these "filter preconditioning steps" was to minimize potential sorbing of plutonium on the filter when the actual samples were filtered. The ultrafilters were then finally used to ultrafilter the higher $20,000 \mathrm{~m}^{-1} \mathrm{SA} / \mathrm{V}$ PCTs and these ultrafiltered leachates were also analyzed by ICP-MS.

All of the leachates were measured for the following elements. Using ICP-AES the leachates were analyzed for B, Na, Li, Si, and $\mathrm{Sr}$ and Al. Using Inductively Coupled Plasma - Mass Spectroscopy (ICPMS) the leachates were analyzed for Pu-239 and 240, La, Nd, Gd, and Hf. The ICP-AES instrument has a nominal instrument detection limit of about $0.01 \mathrm{mg} / \mathrm{L}$ and a $10 \%$ uncertainty in analyses of most elements. The ICP-MS instrument has a nominal instrument detection limit of about $0.01 \mu \mathrm{g} / \mathrm{L}$ and a $20 \%$ uncertainty in analyses. The $\mathrm{pH}$ of the leachates was also measured. A pH meter was used for the low SA/V PCT leachates along with certified buffer solutions. Small drops of the higher SA/V PCT leachates were put onto $\mathrm{pH}$ indicator paper to estimate the $\mathrm{pH}$ of these leachates due to the limited amount of these leachates. 
The Pu glass PCT vessels were acid-stripped after the PCT. This involved removal of the leached powdered glass from the steel and Teflon vessels via remote handling in the SRNL Shielded Cells Facility (SCF). After removal of the leachate from the PCT vessels, the damp, powdered leached glasses were dried in the PCT oven overnight. The dried glass was then poured into a container for archive storage. The empty PCT vessels were then rinsed one time with ASTM Type 1 water. The rinse water was collected and the empty PCT vessels were examined using an ocular eyepiece through the cell window to verify that all visible glass was removed. After these steps, the PCT vessels were removed from the SCF and transferred to a radiochemical hood for acid stripping. A volume of $18 \mathrm{~mL}$ ASTM Type 1 water and 6 drops of concentrated ultrapure nitric acid was added to the vessels that were then heated at $90^{\circ} \mathrm{C}$ for 24 hours. This acid stripping was repeated for a total of three different strips. Each strip solution was analyzed by both ICP-AES and ICP-MS. 
WSRC-TR-2006-00033

Revision 0

This page intentionally left blank. 


\subsection{RESULTS}

\subsection{Glass Fabrication}

\subsection{1 $\mathrm{PuO}_{2}$ Source Material}

The plutonium oxide obtained from ATS personnel was retrieved from a standard that had been previously used in calorimetry equipment development. Therefore, it was expected that $\mathrm{PuO}_{2}$ was of sufficient quality to support this testing without a need for further purification. Analyses were conducted to determine the actinide isotopic distribution as well as screen for the presence of any gross impurity levels in the material.

Liquid scintillation counting and gamma counting were used on the dissolved plutonium oxide solution to determine the isotopic distribution. The analyses indicated that the material was primarily $\mathrm{Pu}-239$ with levels of other plutonium isotopes consistent with what would be found in weapons-grade plutonium. The recovery of $\mathrm{Pu}$ based on the analytical results was $107 \%$. This is greater than $100 \%$ due to analytical error and indicates that the material was likely very pure. The in-growth of Am-241 from decay of $\mathrm{Pu}-241$ in the material was also very low (calculated to be $0.2 \mathrm{wt} \%$ ).

Inductively Coupled Plasma - Atomic Emission Spectroscopy (ICP-AES) was used to screen for the presence of nonradioactive impurities in the $\mathrm{PuO}_{2}$. The analysis was conducted on a standard suite of elements that was expected to encompass any impurities that may be present in the plutonium oxide. The results of the analysis are shown in Table 5. From these analyses, there was some evidence of impurities in the material with the primary impurities being sodium and boron. It was possible that the sodium level resulted from impurities associated with the acid digestions that included relatively large amounts of KF to facilitate dissolution. It was not clear where the boron impurity originated because previous $\mathrm{PuO}_{2}$ analyses had never indicated significant boron impurity levels. ${ }^{9}$ It should be noted that the frit has a large concentration of boron so the presence of a boron impurity at this level in the $\mathrm{PuO}_{2}$ would not impact glass quality. Based on the uncertainty in these measurements and gamma scan and liquid scintillation counting measurements that indicated full Pu recovery, it was determined to proceed with using this material.

\subsubsection{Frit B Preparation}

The two batches of frit were analyzed for use prior to plutonium glass fabrication. Samples of the frit were digested in duplicate and measurements were made using ICP-AES on the duplicates. All frit elements for both batches of the LaBS frit batch were found to be within $+/-10 \%$ of the targeted values. The sum of oxides for the duplicate measurements on the two frit batches ranged from 97.5 to $99.2 \mathrm{wt} \%$ indicating good elemental recovery from the analyses. The measured values (average of the duplicate measurements) vs. targeted are shown in Table 6. 
Table 5. Impurity Concentrations in $\mathrm{PuO}_{2}$ Source Material

\begin{tabular}{|c|c|}
\hline Element & Wt \% \\
\hline $\mathrm{Ag}$ & 0.04 \\
\hline $\mathrm{Al}$ & 1.3 \\
\hline $\mathrm{B}$ & 2.0 \\
\hline $\mathrm{Ba}$ & 0.05 \\
\hline $\mathrm{Ca}$ & 0.3 \\
\hline $\mathrm{Ce}$ & 1.1 \\
\hline $\mathrm{Cr}$ & 0.01 \\
\hline $\mathrm{Cu}$ & 0.2 \\
\hline $\mathrm{Fe}$ & 0.1 \\
\hline $\mathrm{Gd}$ & 0.2 \\
\hline $\mathrm{La}$ & 0.1 \\
\hline $\mathrm{Li}$ & 0.02 \\
\hline $\mathrm{Mg}$ & 0.08 \\
\hline $\mathrm{Mn}$ & 0.05 \\
\hline Mo & 0.1 \\
\hline $\mathrm{Na}$ & 3.2 \\
\hline $\mathrm{Ni}$ & 0.02 \\
\hline $\mathrm{S}$ & 0.1 \\
\hline $\mathrm{Sb}$ & 0.1 \\
\hline $\mathrm{Sn}$ & 0.3 \\
\hline $\mathrm{Sr}$ & 0.1 \\
\hline $\mathrm{Ti}$ & 0.08 \\
\hline $\mathrm{U}$ & 0.8 \\
\hline $\mathrm{Zn}$ & 0.2 \\
\hline $\mathrm{Zr}$ & 0.01 \\
\hline
\end{tabular}

Table 6. Measured (Average of Duplicate Measurements) vs. Targeted Composition for Frit B used in Pu Glass Fabrication

\begin{tabular}{|c|c|c|c|}
\hline Oxide & Target (wt \%) & $\begin{array}{c}\text { Frit B - Batch 1 } \\
(\mathbf{w t} \%)\end{array}$ & $\begin{array}{c}\text { Frit B - Batch 2 } \\
\text { (wt \%) }\end{array}$ \\
\hline $\mathbf{A l}_{\mathbf{2}} \mathbf{O}_{\mathbf{3}}$ & 21.3 & 21.8 & 21.2 \\
\hline $\mathbf{B}_{\mathbf{2}} \mathbf{O}_{\mathbf{3}}$ & 11.6 & 10.6 & 11.8 \\
\hline $\mathbf{G d}_{\mathbf{2}} \mathbf{O}_{\mathbf{3}}$ & 12.8 & 12.4 & 12.4 \\
\hline $\mathbf{H f O}_{\mathbf{2}}$ & 6.6 & 6.7 & 6.1 \\
\hline $\mathbf{L a}_{\mathbf{2}} \mathbf{O}_{\mathbf{3}}$ & 8.1 & 7.7 & 7.8 \\
\hline $\mathbf{N d}_{\mathbf{2}} \mathbf{O}_{\mathbf{3}}$ & 8.2 & 7.9 & 7.6 \\
\hline $\mathbf{S i O}_{\mathbf{2}}$ & 28.9 & 28.2 & 28.9 \\
\hline $\mathbf{S r O}$ & 2.5 & 2.6 & 2.5 \\
\hline $\mathbf{S u m}$ & $\mathbf{1 0 0}$ & $\mathbf{9 7 . 9}$ & $\mathbf{9 8 . 3}$ \\
\hline
\end{tabular}




\subsubsection{Pu Glass Melting}

The $\mathrm{PuO}_{2}$ glass batches were prepared and melted in the SRNL SCF as described in Section 2.2.1. The resulting glass appeared homogenous when visually examined in the crucible. Quenching of the glass was found to be ineffective in facilitating glass removal from the crucible (i.e. the glass did not crack or fracture upon quenching). Thus, the glass was not able to be removed from the crucible via routine means and "hammering" of the glass from the crucible was required. This resulted in pieces of glass (cullet) for follow-on analyses and performance testing. Figure 1 shows the glass cullet from the final $300 \mathrm{~g}$ melt to produce the material for SRNL and PNNL testing. This made it impractical to distinguish where the piece of glass originated with respect to the crucible melt. This precluded the ability to quantify the degree of stratification of $\mathrm{PuO}_{2}$ within the glass melt. Previous analyses by Vienna, et al. identified stratification of $\mathrm{PuO}_{2}$ in plutonium loaded LaBS glasses fabricated in relatively small static crucible melts. ${ }^{10}$ In that testing, it was noted that co-grinding of the frit and $\mathrm{PuO}_{2}$ and/or manual stirring of the melt during processing improved the incorporation of $\mathrm{PuO}_{2}$ into the glass. At this time, neither of those measures could be performed in the SCF. The bar samples sent to ANL will be specifically analyzed to ascertain the degree of stratification in the Pu loaded LaBS glass used in this testing. It should be noted that the Product Consistency Test utilizes ground glass obtained from a bulk sample so the Pu distribution in the sample used for the PCT would be expected to be representative of the bulk glass.

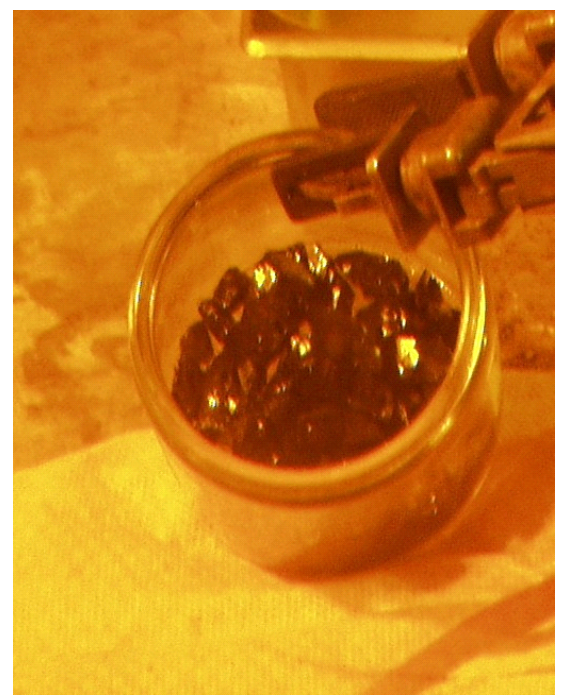

Figure 1. Photograph of Pu LaBS Frit B glass to be used for performance testing.

\subsection{Characterization of Pu LaBS Frit B Glass}

\subsubsection{Initial Pu Glass Characterization}

Shard samples were obtained from Pu glass cullet resulting from the final $300 \mathrm{~g}$ melt. Two shard samples were submitted for both XRD and SEM analyses to provide an initial verification of the homogeneity of the glass. The XRD analyses provided differing results regarding the degree of homogeneity of the glass. Analysis of 1 shard sample indicated the presence of some crystalline $\mathrm{PuO}_{2}$ (Figure 2a) while the second shard sample indicated that the glass was completely amorphous (Figure 2b). The SEM analysis showed only one location where undissolved $\mathrm{PuO}_{2}$ (on the order of $2 \mu \mathrm{m}$ ) was evident (Figure 3). These analyses indicated that there was not gross crystallization or heterogeneity in the glass, however, the observation of crystalline $\mathrm{PuO}_{2}$ in the glass implied the need for further characterization. 


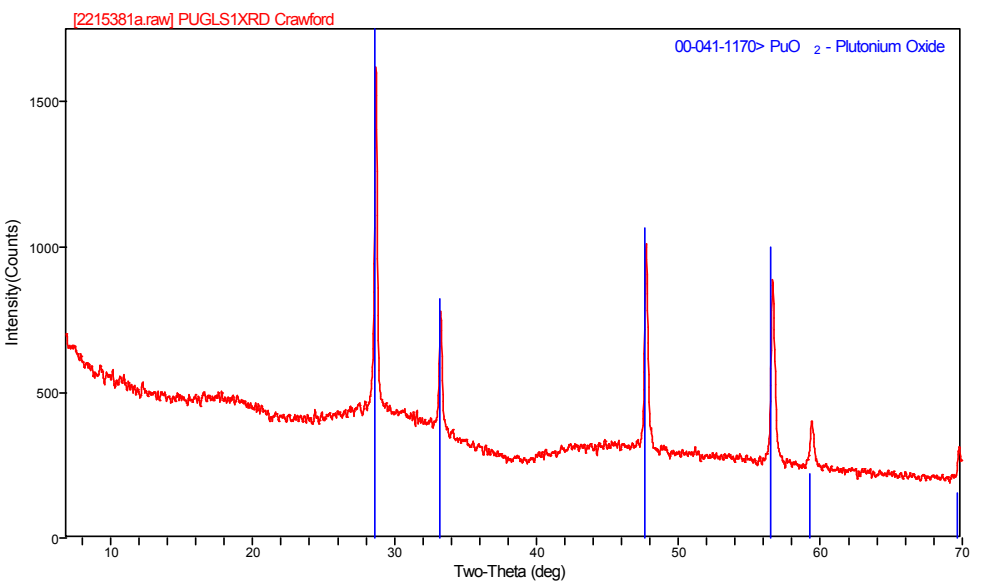

(a)

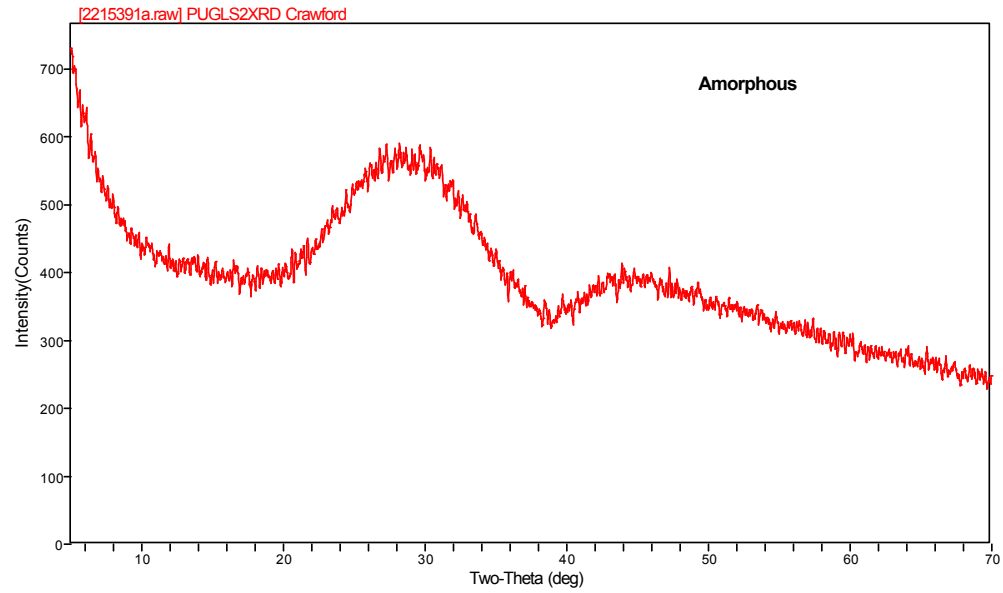

(b)

Figure 2. XRD patterns of Pu LaBS glass shard samples

To conduct the PCTs a glass is ground, sieved and washed. This provides a material with a consistent surface area that is free of fines for subsequent leach testing. It also would provide a significant amount of material surface area for physical examination (recognizing that only two shard samples had been examined to this point). Therefore, a portion of the sieved and washed (unleached) Pu LaBS glass was submitted for SEM and XRD analyses to further evaluate for the presence of undissolved plutonium oxide in the glass. The results indicated that there was some small fraction of $\mathrm{PuO}_{2}$ that was not dissolved in the glass. The XRD analysis again showed the presence of $\mathrm{PuO}_{2}$ in the ground glass sample. However, the relative peak intensities were lower than seen in the previously analyzed shard sample (Figure 4). This indicated that the shard sample showing the relatively strong $\mathrm{PuO}_{2}$ peaks likely included an area that was enriched in undissolved $\mathrm{PuO}_{2}$. The SEM analysis of the ground glass confirmed this result as specific grains were observed to be enriched in undissolved $\mathrm{PuO}_{2}$ (Figure 5) and the $\mathrm{PuO}_{2}$ crystal inclusions had a disk-like morphology. 

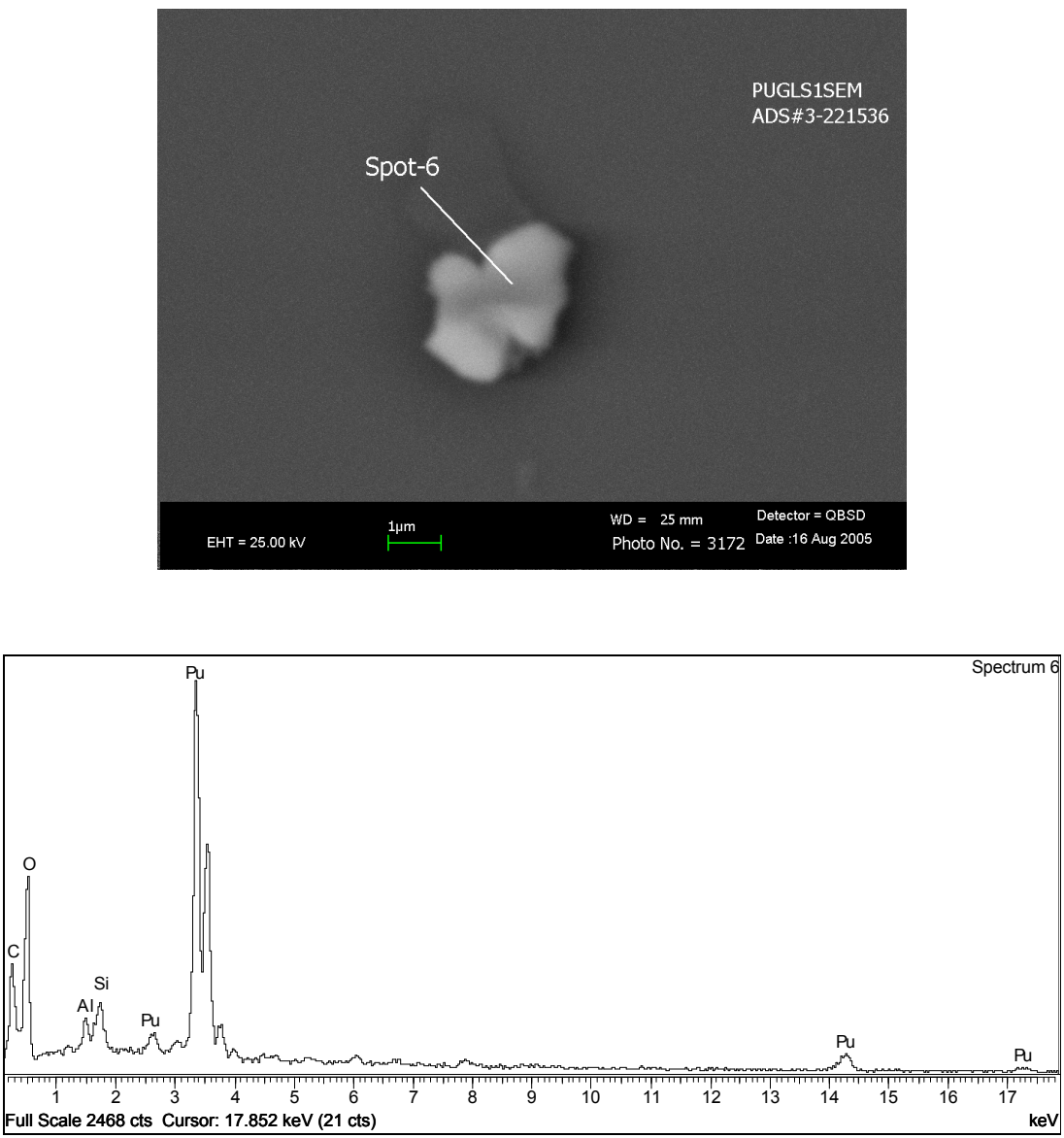

Figure 3. SEM micrograph and corresponding EDS spectrum showing a $\mathrm{PuO}_{2}$ crystal in a Pu LaBS Glass shard sample.

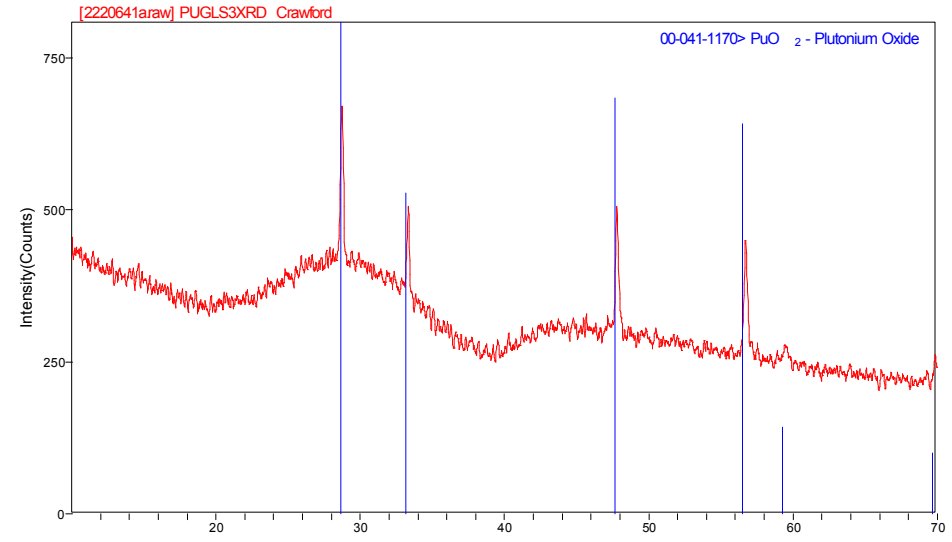

Figure 4. XRD pattern of Pu LaBS glass ground, sieved, and washed sample indicating presence of undissolved $\mathrm{PuO}_{2}$. 

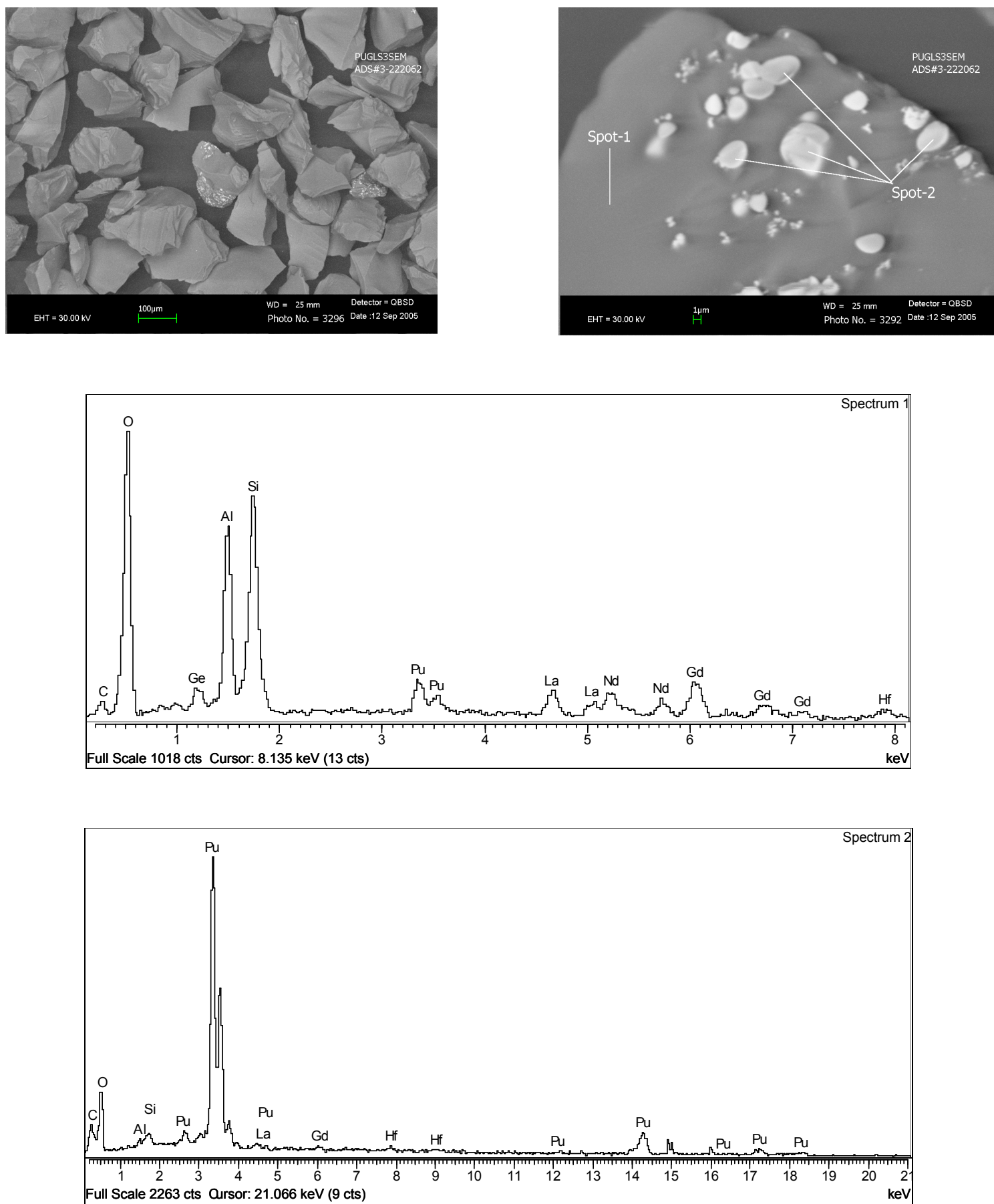

Figure 5. SEM micrographs and corresponding EDS spectra showing undissolved $\mathrm{PuO}_{2}$ crystals in the $\mathrm{Pu}$ LaBS glass 
Recent PNNL results from Pressurized Unsaturated Flow (PUF) testing indicated the potential separation of $\mathrm{Pu}$ from $\mathrm{Gd}$ during the glass dissolution process. ${ }^{11}$ Post-test analysis of the LaBS glass from a 6-year PUF test showed a region where Pu had apparently accumulated in a Pu-bearing disk-like phase that had become separated from the neutron absorber $(\mathrm{Gd})$. The disk-like phase identified by the PNNL researchers had an identical morphology to the phase found in the as-fabricated Pu LaBS Frit B glass observed in this testing. This suggested that the apparent $\mathrm{PuO}_{2}$ separation observed in the PUF test was not due to glass leaching but was a result of glass fabrication.

\subsubsection{Microstructural Analysis of $\mathrm{PuO}_{2}$ Source Material}

Visual examination of the $\mathrm{PuO}_{2}$ source material indicated that it was finely divided and similar to the sized frit used to make the glass (i.e. -325 mesh $(<45 \mu \mathrm{m})$ ). However, to ensure that the undissolved $\mathrm{PuO}_{2}$ crystals were not a result of large particle size starting material, SEM analysis was conducted on a sample of the $\mathrm{PuO}_{2}$. The analysis indicated that the $\mathrm{PuO}_{2}$ was comprised of very fine crystallites (nm-scale) that formed larger agglomerates. Figure 6 shows the SEM images of the $\mathrm{PuO}_{2}$ source material. Based on this observation, it was evident that large particle size $\mathrm{PuO}_{2}$ starting material was not the cause of the undissolved $\mathrm{PuO}_{2}$ in the glass. It was more likely that enriched areas of $\mathrm{PuO}_{2} \mathrm{were}$ formed in the melt (via stratification due to density differences) and that the material in these areas "coarsened" to form the disk-like morphology in the glass. Re-melting of the glass was not sufficient to homogenize the $\mathrm{PuO}_{2}$ in these enriched areas.
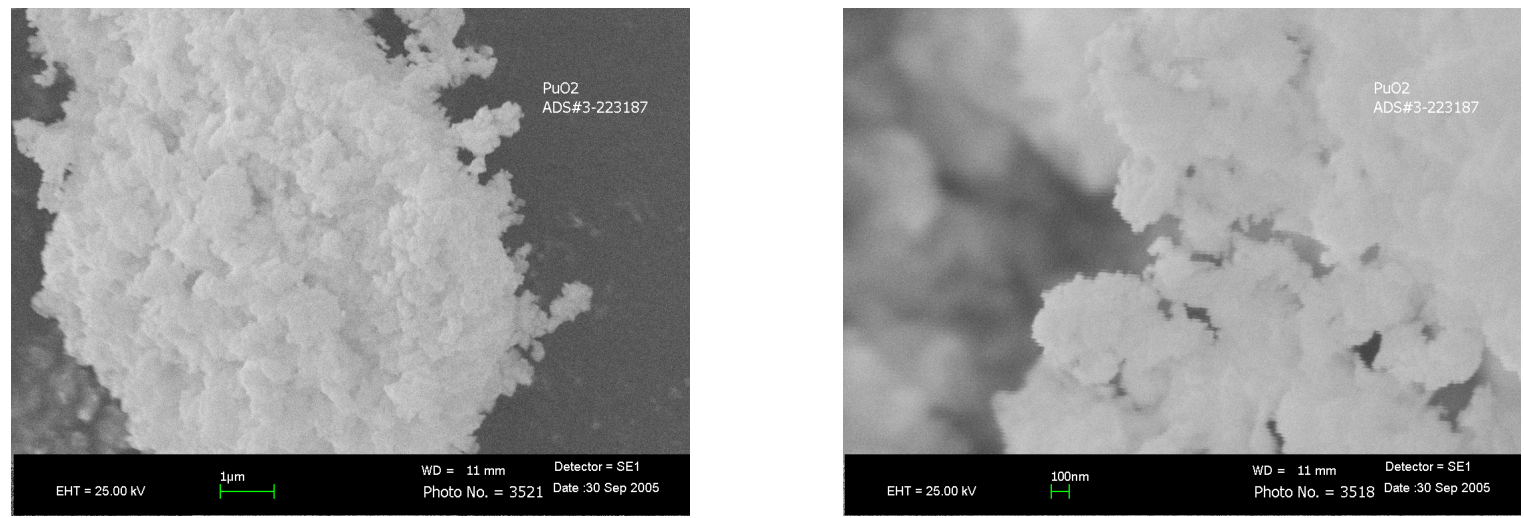

Figure 6. SEM micrographs of $\mathrm{PuO}_{2}$ source material showing the fine crystallite size of the starting material

\subsubsection{Density of Pu LaBS Glass}

Duplicate samples of $>100$ mesh ground glass were used to determine the density of the Pu glass. The density determined was $3.57 \mathrm{~g} / \mathrm{cm}^{3}$ with a standard deviation of 0.01 . The temperature range at which the measurements were made was $28.3-28.8^{\circ} \mathrm{C}$, but since the density variation with temperature for glass is relatively low, this value can be considered relatively constant at ambient temperatures. This density value was used to calculate the mass of glass needed to ensure that the specified surface area was used in the PCTs. 


\subsubsection{Chemical Analysis of Pu Frit B LaBS Glass}

Initial dissolution and analysis testing of surrogate Pu Frit B LaBS glass was conducted using a surrogate containing $\mathrm{Hf}$ in place of the $\mathrm{Pu}$. The goal of these initial glass dissolutions and analyses was to confirm that the $>200$ mesh to $<100$ mesh glass powders could be used in sodium peroxide fusion with a nitric acid uptake. Routine radioactive glass analyses typically use $<200$ mesh glass powder and $\mathrm{HCl}$ acid uptake in the peroxide fusion method. However, it was desirable to use the larger size $>200$ mesh to $<100$ mesh Pu glass powders for dissolution and analyses so that the data would be representative of the same size glass powders that were leached in the PCT. Use of nitric acid in place of $\mathrm{HCl}$ facilitates excess sample disposal via the high activity drains within the SRNL SCF. Table 7 shows the results of the Pu surrogate glass fusion and analyses. The surrogate glass analyses were all performed using ICPAES. Table 7 shows that no significant differences are found in the powder size or the acid used in the Pu surrogate glass dissolutions. All of the analyzed wt $\%$ oxide values are within $4 \%$ of target except for $\mathrm{HfO}_{2}$ and $\mathrm{Nd}_{2} \mathrm{O}_{3}$. These two analytes were measured to be 7 to $8 \%$ lower than target on an oxide basis.. 
Table 7. Measured vs. Targeted Wt\% Composition for Pu Frit B Surrogate Glass

\begin{tabular}{|c|c|c|c|c|c|c|c|c|c|c|}
\hline Sample ID & $\mathbf{A l}$ & $\mathbf{B}$ & $\mathbf{F e}$ & Gd & Hf & $\mathbf{L a}$ & Nd & Si & $\mathbf{S r}$ & \\
\hline LaBS Frit 100-200 m esh HCl & 10.6 & 3.18 & $<\mathbf{0 . 0 1 0}$ & 10.2 & 12.2 & 6.24 & 5.96 & 12.2 & 1.91 & \\
\hline LaBS Frit >200 mes h HCl & 10.5 & 3.19 & 0.357 & 10.2 & 12.2 & 6.22 & 5.86 & 12.2 & 1.88 & \\
\hline LaBS Frit 100-200 m esh HNO3 & 10.6 & 3.20 & $<\mathbf{0 . 0 1 0}$ & 10.3 & 12.2 & 6.25 & 5.97 & 12.2 & 1.93 & \\
\hline LaBS Frit >200 mes h HNO3 & 10.6 & 3.12 & 0.380 & 10.0 & 12.0 & 6.07 & 5.81 & 12.0 & 1.86 & \\
\hline & Al2O3 & B2O3 & Fe2O3 & Gd2O3 & HfO2 & La2O3 & Nd2O3 & SiO2 & SrO & Total \\
\hline LaBS Frit 100-200 m esh HCl & 20.0 & 10.2 & $\mathbf{0 . 0 0 0}$ & 11.7 & 14.4 & 7.30 & 6.97 & 26.1 & 2.25 & 99.0 \\
\hline LaBS Frit >200 mesh HCl & 19.8 & 10.3 & 0.511 & 11.7 & 14.4 & 7.28 & 6.86 & 26.1 & 2.22 & 99.2 \\
\hline LaBS Frit 100-200 m esh HNO3 & 20.0 & 10.3 & $\mathbf{0 . 0 0 0}$ & 11.8 & 14.4 & 7.31 & 6.98 & 26.1 & 2.28 & 99.3 \\
\hline LaBS Frit $>200$ mesh HNO3 & 20.0 & 10.0 & 0.543 & 11.5 & 14.2 & 7.10 & 6.80 & 25.7 & 2.19 & 98.1 \\
\hline Average Analyzed Oxide & 20.0 & 10.2 & & 11.7 & 14.3 & 7.2 & 6.9 & 26.0 & 2.2 & 98.9 \\
\hline Target Oxide & 19.28 & 10.5 & & 11.58 & 15.5 & 7.33 & 7.4 & 26.16 & 2.26 & 100.01 \\
\hline Percent Diff. (Anal. Vs. Target) & 4 & -3 & & $\mathbf{1}$ & -8 & -1 & -7 & -1 & -1 & \\
\hline
\end{tabular}


The Pu glasses were dissolved in the SCF by remote handling and aliquots of the dissolved Pu glasses were removed from the SCF and transferred to the ICP-AES and ICP-MS labs for analyses. However, due to discrepancies in the glass composition data from these measurements, the data are not reported and were not utilized in normalized release calculations. Therefore, the normalized release data provided in this report were based on targeted glass composition values. This is expected to only have a minor impact on the calculations (the current analytical data set shows that no glass constituent varies from the targeted value by more than $30 \%$ and most varied by less than $10 \%$ ). The composition data will be obtained and normalized elemental release rates recalculated to finalize the dataset.

\subsection{Results of PCT-A and PCT-B Tests on Pu Frit B Glass}

As mentioned before, the PCT is a crushed glass leach test at $90^{\circ} \mathrm{C}$. Both the PCT-A and the PCT-B type tests were performed on the Pu LaBS glass prepared with Frit B. Table 8 shows a summary of the various PCTs performed on the Pu Frit B LaBS glass. The first three tests are PCT-A conditions. The blank tests performed with ASTM Type 1 water are also included for comparison. All other tests are PCT-Bs including two blank tests performed for the longest duration of 56 days. All tests were performed remotely in the SCF of SRNL. The PCTs performed in steel vessels used a wrench and holder system to tighten the vessels. The PCTs performed in Teflon vessels used a mechanical 'capping station' supplied by CEM Corp. This model \#920030 capping station provided a nominal $5 \mathrm{ft} / \mathrm{lb}$ torque to tighten the Teflon vessels. It is interesting to note that Table 8 shows that the average mass loss from the steel vessels and from the Teflon vessels was the same at $\sim 0.010 \mathrm{~g} /$ day. Note that all the tests except for the PCT-B tests at the high SA/V for 28 day and 56 days met the ASTM requirement that leachate mass loss is $<5 \%$.

The last column of Table 8 also shows that only about $50 \%$ of the original starting leachant was recovered from the high $20,000 \mathrm{~m}^{-1} \mathrm{SA} / \mathrm{V}$ tests. This was mainly due to the fact that there was a very little amount of free liquid volume in these high SA/V PCT-B tests. In the PCT-A tests the leachate was collected at the end of the test by decanting the free liquid from the PCT vessel into a clean specimen bottle by remote handling in the SCF. That bottle was then transferred from the SCF to a radiochemical hood for syringe filtration. However, in the PCT-B tests at high SA/V, the leachate was decanted directly into a syringe that was pre-fit with a filter. The PCT-B tests at high SA/V were thus directly syringe-filtered in the SCF by remote handling. 
Table 8. Summary of PCT-A and PCT-B Tests Performed on Pu Frit B LaBS Glass

\begin{tabular}{|c|c|c|c|c|c|c|c|c|c|c|c|c|}
\hline $\begin{array}{l}\text { PCT } \\
\text { Method }\end{array}$ & $\begin{array}{c}\text { Vessel } \\
\text { Type and } \\
\text { ID* }\end{array}$ & Sample ID & Glass Mass $(\mathrm{g})$ & $\begin{array}{l}\text { Leachant } \\
\text { Mass }(\mathrm{g})\end{array}$ & $\begin{array}{c}\text { Ratio Leachant } \\
\text { to Glass }\end{array}$ & $\operatorname{SA} / V\left(m^{\wedge}-1\right)$ & $\begin{array}{c}\text { PCT Duration } \\
\text { (Days) }\end{array}$ & Mass Loss & $\begin{array}{l}\% \text { Leachate } \\
\text { Mass Loss }\end{array}$ & $\begin{array}{c}\text { Avg. Leachate Mass } \\
\text { Loss per Day }\end{array}$ & $\begin{array}{c}\text { Mass Leachate } \\
\text { Filtered }\end{array}$ & $\begin{array}{c}\% \text { Ratio: } \\
\text { Filtered/Starting }\end{array}$ \\
\hline PCT-A & S-203 & $\mathrm{Pu}-1$ & 1.773 & 17.756 & 10.01 & 1505 & $\overline{7}$ & 0.069 & 0.4 & 0.010 & 13.987 & 79 \\
\hline & & & & & & & & & & & & \\
\hline PCT-A & S-253 & $\mathrm{Pu}-2$ & 1.778 & 17.734 & 9.97 & 1511 & 7 & 0.121 & 0.7 & 0.017 & 12.947 & 73 \\
\hline PCT-A & S-255 & Pu-3 & 1.725 & 17.262 & 10.01 & 1506 & 7 & 0.053 & 0.3 & 0.008 & 13.054 & 76 \\
\hline & & & & & & & & & & & & \\
\hline PCT-A & S-210 & Blk-1 & $\overline{N A}$ & 17.838 & $\overline{N A}$ & $\mathrm{NA}$ & 7 & 0.135 & 0.8 & 0.019 & 15.417 & 86 \\
\hline PCT-A & S-250 & Blk-2 & $\overline{N A}$ & 17.839 & $\mathrm{NA}$ & $\overline{N A}$ & 7 & 0.099 & 0.6 & 0.014 & 15.348 & 86 \\
\hline & & & & & & & & & & & & \\
\hline PCT-A & S-261 & Blk-3 & NA & 17.932 & $\mathrm{NA}$ & $\mathrm{NA}$ & 7 & 0.055 & 0.3 & 0.008 & 15.046 & 84 \\
\hline PCT-B & S-258 & $P_{\Perp-4}$ & 2341 & 16763 & 716 & 2104 & 7 & 0098 & 06 & 0014 & 12904 & 77 \\
\hline & & & & & & & & & & & & \\
\hline PCT-B & S-B31 & Pu-5 & 2.213 & 15.981 & 7.22 & 2087 & 7 & 0.058 & 0.4 & 0.008 & 11.777 & 74 \\
\hline & & & & & & & & & & & & \\
\hline PCT-B & S-461 & $\mathrm{Pu}-6$ & 2.232 & 16.135 & 7.23 & 2084 & 7 & 0.036 & 0.2 & 0.005 & 11.685 & 72 \\
\hline PCT-B & $\bar{T}-172$ & $\mathrm{Pu}-7$ & 1.801 & 18.064 & 10.03 & 1502 & 7 & 0.085 & 0.5 & 0.012 & 14.56 & 81 \\
\hline & & & & & & & & & & & & \\
\hline PCT-B & T-146 & Pu-8 & 1.83 & 18.29 & 9.99 & 1508 & 14 & 0.153 & 0.8 & 0.011 & 14.651 & 80 \\
\hline PCT-B & $\mathrm{T}-156$ & Pu-B-7 & 6.984 & 5.093 & 0.73 & 20663 & 7 & 0.062 & 1.2 & 0.009 & 2.762 & 54 \\
\hline & & & & & & & & & & & & \\
\hline PCT-B & $T-133$ & Pu-B-7-rep & 6.992 & 5.079 & 0.73 & 20743 & 7 & 0.1 & 2.0 & 0.014 & 2.086 & 41 \\
\hline PCT-B & $T 110$ & $\mathrm{D}_{1} \mathrm{P} 114$ & 6005 & 5062 & 72 & 20010 & 11 & 111 & 23 & 0008 & 2501 & 51 \\
\hline & & & & & & & 14 & & & & & \\
\hline PCT-B & $\mathrm{T}-107$ & Pu-B-28 & 7.018 & 5.136 & 0.73 & 20590 & 28 & 0.265 & 5.2 & 0.009 & 2.445 & 48 \\
\hline PCT-B & $\mathrm{T}-129$ & Pu-B-56 & 6.995 & 5.093 & 0.73 & 20695 & 56 & 0.502 & 9.9 & 0.009 & 2.14 & 42 \\
\hline & & & & & & & & & & & & \\
\hline PCT-B & $\mathrm{T}-74$ & Blnk-1 & $\mathrm{NA}$ & 5.053 & $\mathrm{NA}$ & $\mathrm{NA}$ & 56 & 0.542 & 10.7 & 0.010 & 3.927 & 78 \\
\hline & & & & & & & & & & & & \\
\hline PCT-B & $\mathrm{T}-143$ & Blnk-2 & $\overline{\mathrm{NA}}$ & 5.068 & $\overline{N A}$ & $\overline{\mathrm{NA}}$ & 56 & 0.486 & 9.6 & 0.009 & 3.945 & 78 \\
\hline
\end{tabular}




\subsubsection{Comparison of Normalized Releases of Pu Glass and EA Glass in PCT-A}

The PCT-A test was developed to determine if a glass meets the durability criterion in the WAPS. ${ }^{2}$ This criterion states that the normalized releases for $\mathrm{B}, \mathrm{Li}$ and $\mathrm{Na}$ are less than those for the elements in the EA glass. ${ }^{12}$ The PCT-A procedure specifically states that SA/V = 10:1. The ARM glass is used in the PCT to confirm that test conditions for the PCT were properly controlled. ${ }^{13}$ This is accomplished by comparison of the ARM glass leach test data to historical databases from previous PCT tasks. ${ }^{14}$ Table 9 gives the average concentrations in ppm of $\mathrm{B}, \mathrm{Si}, \mathrm{Li}$ and $\mathrm{Na}$, in the final leachates after the tests. The averages of the final $\mathrm{pH}$ values of the leachates are also presented. The concentrations were corrected for the acidification dilutions of the leachates as required by the ASTM procedure.

Table 9. Average Concentrations (ppm) of B, Si, Li and Na, and the Final pH from the $90{ }^{\circ} \mathrm{C} \mathrm{PCT}$ Based on Triplicate PCT-A Tests and Blanks

\begin{tabular}{|c|c|c|c|c|c|}
\hline Sample ID & $\mathbf{B}$ & $\mathbf{S i}$ & $\mathbf{L i}$ & $\mathbf{N a}$ & $\mathbf{p H}(\mathbf{b})$ \\
\hline Blanks & $<0.11$ & $<0.54$ & $<0.05$ & $<0.39$ & 6.9 \\
\hline ARM(a) & 18.8 & 65.8 & 14.6 & 39.5 & 10.4 \\
\hline EA Glass & 628 & 928 & 184 & 1683 & 12.0 \\
\hline $\begin{array}{c}\text { Pu LaBS Glass } \\
\text { FRIT B }\end{array}$ & 0.18 & $<0.54$ & $\mathrm{NP}(\mathrm{c})$ & $\mathrm{NP}$ & 7.2 \\
\hline
\end{tabular}

(a) Control Chart Ranges for ARM Glass: B, 13-23 ppm; Si, 49-73 ppm; Li, 11-16 ppm;

and $\mathrm{Na}, 29-44 \mathrm{ppm}$. See Reference 14.

(b) Initial $\mathrm{pH}$ of the leach water was also 6.9.

(c) NP - Not Present in the glass

The results for the blanks indicated that contamination of the leachates from possible impurities in the water or impurities on the stainless steel vessels was negligible. The results for the standard ARM-1 glass were compared to a control chart based on results for previous PCTs on this standard glass. ${ }^{12}$ This comparison is part of the ASTM procedure. As shown in Table 9, the results for the ARM glass were between the lower and upper control limits (Reference 14), indicating that the test conditions were properly controlled. A multi-element solution standard containing $\mathrm{B}, \mathrm{Si}, \mathrm{Li}$, and $\mathrm{Na}$ in the concentration range of 10 to $80 \mathrm{mg} / \mathrm{L}$ was submitted for analysis in parallel with the leachates. The measured results agreed within $10 \%$ or less of the known values indicating that the ICP-AES analyses were sufficiently accurate.

Thus, since no impurities were determined in the blanks, and the standard ARM-1 results were within the lower and upper bounds of historical PCTs, and analysis of multi-element standard solutions were within the nominal 10\% uncertainty of the analytical instrumentation, the results of the PCT-A test performed on the radioactive $\mathrm{Pu} \mathrm{LaBS}$ Frit B glass were considered acceptable.

The final $\mathrm{pH}$ is an approximate indication of the relative durability of various glasses in a PCT. In general, the higher the final $\mathrm{pH}$ the lower the durability (as defined by the PCT). Based on the $\mathrm{pH}$ results the LaBS Pu glass appeared more durable than the EA glass (a $\mathrm{pH}$ of 7.2 versus 12). Normalized mass losses are the best indication of the durability of a glass in a PCT. Normalization accounts for the concentration of an element in the glass. 
The normalized release is a measure of the total mass of glass dissolved in a PCT based on a specific element in the glass. Per the ASTM PCT procedure, the normalized concentration is the grams of glass dissolved per liter of leachate $(\mathrm{g} / \mathrm{L})$ based on a specific element calculated from the following equation as:

$$
\mathrm{NC}_{\mathrm{i}}=\mathrm{c}_{\mathrm{i}}(\text { sample }) / \mathrm{f}_{\mathrm{i}}
$$

Where: $\mathrm{NC}_{\mathrm{i}}$ is normalized concentration for leached glass based on element $\mathrm{i}$, in grams of glass dissolved per Liter of leachate. $\mathrm{c}_{i}$ (sample) is the concentration of element " $i$ " in $g / L$ in the leachate, and $f_{i}$ is the fraction of element " $i$ " in the unleached glass (unitless).

The results in Table 10 clearly indicated that based on $\mathrm{B}$, the leachability of the Pu LaBS glass is orders of magnitude less than that for the EA glass. On this basis it meets the criterion for durability in the WAPS. The data was also comparable with data obtained from previous LaBS Frit B PCT-A testing (Table 4). The normalized releases for B and $\mathrm{Sr}$ were nearly equal indicating congruent dissolution for based on these two elements. Note that all the other normalized releases were much lower that those based on B and Sr. It should be noted that the results in Table 10 were based on solution analysis only and did not include elements that may be sorbed on the walls of the steel vessel. The effect of elements sorbing on the walls will be discussed later in the report. Lastly, it is important to note from Table 3-6 that comparison of the EA normalized concentrations from the PCT-A test performed in this study with normalized EA concentrations from the published study indicated that the normalized EA concentration data in this study were within the average \pm 1 standard deviation of the published values for $\mathrm{B}, \mathrm{Na}, \mathrm{Li}$ and Si.

Table 10. Average Normalized (Grams Glass/L) PCT-A Results for Pu FRIT B and EA Glass Based on Triplicate Tests

\begin{tabular}{cccc}
\hline Element & $\begin{array}{c}\text { Measured Pu LaBS } \\
\text { g/L (Std. Dev., \%RSD) }\end{array}$ & $\begin{array}{c}\text { Measured EA } \\
\text { g/Ltd. Dev., \%RSD) }\end{array}$ & $\begin{array}{c}\text { Published EA }^{\mathbf{1 2}} \\
\text { g/L (Std. Dev., \%RSD) }\end{array}$ \\
\hline $\mathrm{B}$ & $0.018(0.001,7.1)$ & $18.0(0.2,1)$ & $16.7(1.2,7)$ \\
$\mathrm{Na}$ & $\mathrm{NP}^{\mathrm{a}}$ & $12.5(0.3,2.3)$ & $13.3(0.9,7)$ \\
$\mathrm{Li}$ & $\mathrm{NP}$ & $9.4(0.1,2.0)$ & $9.6(0.7,7)$ \\
$\mathrm{Si}$ & $<0.015$ & $4.1(0.3,2.3)$ & $3.9(0.4,10)$ \\
$\mathrm{Sr}$ & $0.016(0.001,7.0)$ & $\mathrm{NP}$ & $\mathrm{NP}$ \\
$\mathrm{Pu}-239$ & $0.0042(.0004,10)$ & $\mathrm{NP}$ & $\mathrm{NP}$ \\
$\mathrm{La}$ & $0.00069(0.00015,22)$ & $\mathrm{NP}$ & $\mathrm{NP}$ \\
$\mathrm{Nd}$ & $0.00018(0.00009,27)$ & $\mathrm{NP}$ & $\mathrm{NP}$ \\
$\mathrm{Gd}$ & $0.00080(0.000030,38)$ & $\mathrm{NP}$ & $\mathrm{NP}$ \\
$\mathrm{Hf}$ & $0.00012,(0.000007,57)$ & $\mathrm{NP}$ & $\mathrm{NP}$ \\
$\mathrm{pH}$ & 7.20 & 12.0 & 11.9 \\
\hline
\end{tabular}

${ }^{a} \mathrm{NP}$ means that this element was not present in the glass. 


\subsubsection{Examination of Leached PCT-A Pu Glass by SEM}

Following the PCT-A testing, a sample of leached glass was obtained from the 7 day exposure tests for analysis. The sample was dried overnight in the PCT oven to facilitate handling. A sample of the dried glass was placed on an aluminum stub for SEM analysis. The SEM results showed no evidence of alteration phase formation on the glass surface, however, the undissolved $\mathrm{PuO}_{2}$ disk-like phase was again evident on some glass grains (Figure 7).
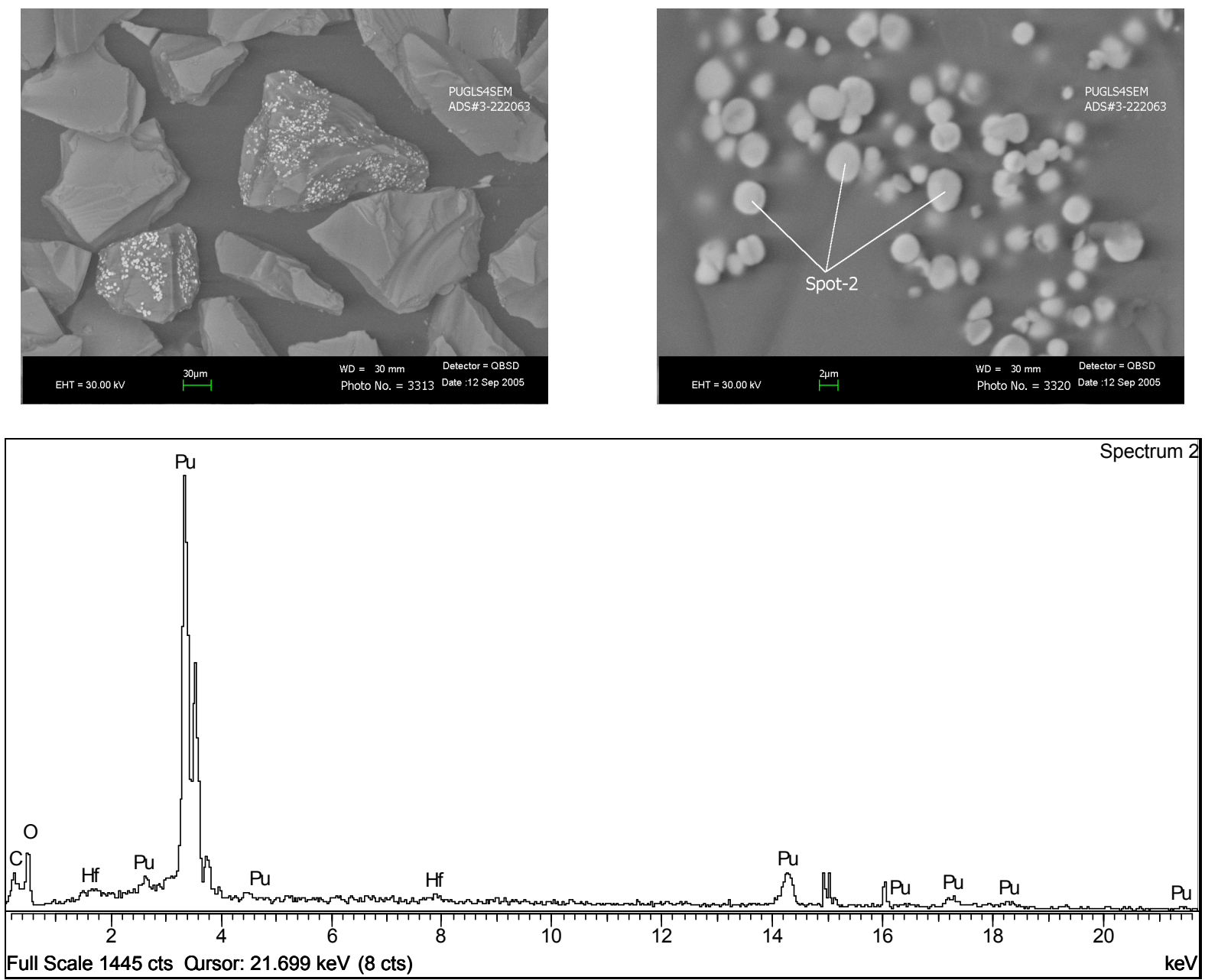

Figure 7. SEM micrographs and corresponding EDS spectra of leached Pu LaBS glass showing undissolved $\mathrm{PuO}_{2}$ crystals but no alteration phase formation 


\subsubsection{Results of 7 Day PCT-B Tests at SA/V of 1500 and $2100 \mathrm{~m}^{-1}$}

The density of the Pu LaBS glass is greater than a Sodium Borosilicate (NaBS) glass such as a typical DWPF glass. A typical DWPF glass has a density of nominally $2.58 \mathrm{~g} / \mathrm{cm}^{3}$ while the Pu LaBS glass fabricated from Frit B had a density of $3.57 \mathrm{~g} / \mathrm{cm}^{3}$. Consequently in a PCT-A with a ratio of $10 \mathrm{~mL}$ of leachant per gram of glass, there would be less surface area of glass exposed to the leachant with the higher density glass. To correct for this, triplicate PCT-B tests were performed with Pu LaBS glass where the ratio of the surface area to the volume of leachant $(\mathrm{SA} / \mathrm{V})$ was comparable to a PCT-A test with a DWPF glass. Consequently for the PCT with Pu LaBS glass the $7.23 \mathrm{~mL}$ of leachant $(10 \times(2.58 / 3.57)$ was used per gram of Pu LaBS glass. These were not PCT-A tests because the ASTM procedure specially states that for a PCT-A test the ratio of leachant volume to mass of glass has to be $10.0 \pm 0.5 \mathrm{~cm}^{3} /$ gram of sample.

In the PCT, the glass is carefully sieved through standard mesh size sieves so that the surface area of the glass is reproducible from test to test. The exposed surface area of the glass in a PCT has been estimated by assuming that the particles are spherical and that the distribution of particle sizes is Gaussian ${ }^{12}$. The size of the holes in the 100 and 200 mesh sieves are $0.149 \mathrm{~mm}$ and $0.074 \mathrm{~mm}$, respectively. Thus the diameter of the spheres range between these two values with an average value of $1.12 \mathrm{E}-04 \mathrm{~m}$. Based on these assumptions the exposed surface area in a PCT with the Pu LaBS glass was calculated to be 0.015 $\mathrm{m}^{2}$ per gram of sieved glass. Since the density of the Pu LaBS glass was 3.57 grams this gave a SA/V for the PCT-A tests of $1500 \mathrm{~m}^{-1}$. Per the ASTM PCT procedure, the normalized mass loss in terms of grams of glass leached per square meter for PCT-A is calculated using the following equation:

$$
\mathrm{NL}_{\mathrm{i}}=\mathrm{c}_{\mathrm{i}}(\text { sample }) /\left(\mathrm{f}_{\mathrm{i}}\right) \times(\mathrm{SA} / \mathrm{V})
$$

where: $\mathrm{NL}_{\mathrm{i}}$ is normalized release based on element $\mathrm{i}$, in grams of glass leached per square meter of glass exposed in the PCT-A, $c_{i}$ (sample) is the concentration of element " $i$ " in $g / L$ in the leachate, and $f_{i}$ is the fraction of element "i" in the unleached glass (unitless), and SA/V is the surface area of the glass divided by the leachate volume in units of $\mathrm{m}^{2} / \mathrm{L}$

Note that the $\mathrm{SA} / \mathrm{V}$ for the $\mathrm{Pu}$ LaBS glass of $1500 \mathrm{~m}^{-1}$ expressed in terms of $\mathrm{m}^{2} / \mathrm{L}$ is:

$$
1500 \mathrm{~m}^{-1} \times\left[\left(1 \mathrm{~m}^{2} / \mathrm{L}\right) / 1000 \mathrm{~m}^{-1}\right]=1.5 \mathrm{~m}^{2} / \mathrm{L} \text {. }
$$

The results for the PCTs performed at the different S/V ratios are shown in Table 11. The results indicated that for the most part the normalized releases in both series of tests were the same based on identical elements. Again, it should be stated that these results are based solely on concentrations measured in solution. 
Table 11. Average Normalized Releases (Grams Glass $/ \mathbf{m}^{2}$ ) in PCT Tests at $\mathrm{SA} / \mathrm{V}$ Ratios of 1500 and $2100 \mathrm{~m}^{-1}$ in Steel Vessels ${ }^{\mathrm{a}}$

\begin{tabular}{|c|c|c|}
\hline Element & $\begin{array}{c}\text { g/m } \text { (Std. Dev., \%RSD) }^{2} \text { SA } / \mathrm{V}=1500 \mathrm{~m}^{-1} \\
\end{array}$ & $\begin{array}{c}\text { g/m } \text { m }^{2} \text { (Std. Dev., \%RSD) } \\
\text { SA } / \mathrm{V}=2100 \mathrm{~m}^{-1}\end{array}$ \\
\hline B & $1.2 \mathrm{E}-02(8.5 \mathrm{E}-04,7.1)$ & 1.3E-02 (9.1E-04, 7.0) \\
\hline Si & $<9.8 \mathrm{E}-03$ & $<7.0 \mathrm{E}-03$ \\
\hline Sr & $1.1 \mathrm{E}-02(7.7 \mathrm{E}-04,7.0)$ & 1.0E-02 (2.2E-04, 2.2) \\
\hline Pu-239 & $2.8 \mathrm{E}-03(2.8 \mathrm{E}-04,10)$ & 2.4E-03 (1.8E-04, 7.5) \\
\hline $\mathbf{L a}$ & 4.6E-04 (9.9E-05, 22) & 1.9E-04 (1.1E-04, 60) \\
\hline Nd & $1.2 \mathrm{E}-04(3.2 \mathrm{E}-05,27)$ & $1.0 \mathrm{E}-04(4.8 \mathrm{E}-05,48)$ \\
\hline Gd & $5.3 \mathrm{E}-05(2.0 \mathrm{E}-05,38)$ & 5E-05 $(8 \mathrm{E}-06,16)$ \\
\hline Hf & $8 \mathrm{E}-06(2 \mathrm{E}-06,57)^{\mathrm{b}}$ & $4 \mathrm{E}-06^{\mathrm{b}, \mathrm{c}}$ \\
\hline
\end{tabular}

${ }^{a}$ Results are averages of triplicate tests. The tests at SA/V at $1500 \mathrm{~m}^{-1}$ were PCT-A tests whose results are presented in Table 3-6 on a normalized $\mathrm{g} / \mathrm{L}$ basis.

${ }^{\mathrm{b}}$ The concentrations in the leachates were so low that only one significant figure was presented in the ICP-MS results.

${ }^{c}$ Again the concentration of $\mathrm{Hf}$ was so low in the leachates that only one significant figure was presented in the ICP-MS results and all the concentration were the same.

\subsubsection{Results of 7 and 14 Day PCT-B Tests at SA/V of 1500 and $21000 \mathrm{~m}^{-1}$}

The PCT results for PCT-B tests in Teflon vessels for seven and fourteen days at the two different SA/V ratios of 1500 and $21000 \mathrm{~m}^{-1}$ are shown in Table 3-8. The seven day PCT data are shown in the first two data rows (Pu-7 and $\mathrm{Pu}-\mathrm{B}-7)$ and the fourteen day PCT data are shown in the latter two rows (Pu-8 and $\mathrm{Pu}-14)$. The seven day PCT data at SA/V of $20,700 \mathrm{~m}^{-1}$ was the average of duplicate tests that were performed at different times. As was shown in the previous section for comparison of 7 day PCT normalized release in steel at 1500 and $2100 \mathrm{~m}^{-1}$, these data presented in Table 12 also indicated that for the most part the normalized releases in all four series of tests were very similar. This is obvious from comparing the boron normalized releases (in the range of $6.5 \mathrm{E}-3$ to $1.6 \mathrm{E}-2 \mathrm{~g} / \mathrm{m}^{2}$ ) and also from comparing the Pu normalized releases (in the range of $1.2 \mathrm{E}-3$ to $3.7 \mathrm{E}-3 \mathrm{~g} / \mathrm{m}^{2}$ ).

Comparisons can also be made between the normalized release of the PCT-A results performed in triplicate steel vessels at a water to glass ratio of $10 \mathrm{X}$ and the single similar PCT that was performed in a Teflon $^{\circledR}$ vessel. Table 13 shows these normalized filtered leachate data to be very similar indicating that the vessel material has insignificant influence on the filtered leachate concentrations. The normalized B and $\mathrm{Sr}$ values were essentially the same in the triplicate steel vs. the single Teflon ${ }^{\circledR}$ vessel. 


\subsubsection{Results of 7 Through 56 Day PCT-B Tests at SA/V of $21000 \mathrm{~m}^{-1}$}

Table 14 shows normalized releases for all of the PCTs at SA/V ratios near $21000 \mathrm{~m}^{-1}$. The normalized releases for boron, silicon, strontium and plutonium perhaps showed an increase of about $2 \mathrm{X}$ to $3 \mathrm{X}$ as the leaching time increased from seven to fifty-six days. The normalized releases for $\mathrm{B}, \mathrm{Si}$ and $\mathrm{Sr}$ were also higher than for the other elements in the glass ( $\mathrm{La}, \mathrm{Nd}, \mathrm{Gd}, \mathrm{Hf}$ and $\mathrm{Pu}$ ) for each time duration tested. This indicated that the degradation rate of the glass matrix as determined by the release of $\mathrm{B}, \mathrm{Si}$ and $\mathrm{Sr}$, generally bound the release of $\mathrm{La}, \mathrm{Nd}, \mathrm{Gd}, \mathrm{Hf}$ and $\mathrm{Pu}$.

\subsubsection{Results of Filtered vs. Ultrafiltered PCT-A and PCT-B Tests}

Table 15 compares the normalized releases for the filtered vs. the ultrafiltered leachates from the PCT-A and PCT-B tests. The ultrafiltered leachates were only analyzed by ICP-MS due to volume limitations on the amount of ultrafiltered product. Comparison of the plutonium normalized releases showed that ultrafiltering did not have a significant influence on the amount of plutonium present in the filtered products. The last column of Table 15 showed that filtered and ultrafiltered leachates had nearly the same normalized release values. Comparison of the PCT-A normalized Pu release for filtered vs. ultrafiltered ( $\mathrm{Pu}-1$ through $\mathrm{Pu}-3$ data) showed that the average normalized release for $\mathrm{Pu}$ is the same for filtered and ultrafiltered to within two standard deviations. The normalized release rates for filtered and unfiltered samples calculated from the PCT-B data at SA/V of 2100 m-1 (Pu-3 through Pu-6 data) were within one standard deviation. The seven and fourteen day PCT-B normalized Pu release filtered and ultrafiltered data at SA/V of $\sim 21000 \mathrm{~m}^{-1}$ were nearly identical. Ultrafiltration normalized release for the 7 and 14 day PCT-B at SA/V of $1500 \mathrm{~m}^{-1}$, as well as the ultrafiltration normalized release for the 28 and 56 day PCT-B did show slightly lower values when compared to the analogous filtered normalized releases. However, these differences were likely within the analytical uncertainty of the ICP-MS analyses that are reported at $\pm 20 \%$. 
Table 12. Average Normalized Releases (Grams Glass $/ \mathrm{m}^{2}$ ) in PCT-B Tests at $\mathrm{SA} / \mathrm{V}$ Ratios of 1500 and $21000 \mathrm{~m}^{-1}$ in Teflon Vessels

\begin{tabular}{|c|c|c|c|c|c|c|c|c|c|c|c|c|c|}
\hline & $\mathrm{SA} / \mathrm{V}$ & B & & $\mathrm{Si}$ & $\mathrm{Sr}$ & $\mathrm{La}$ & & $\mathrm{Nd}$ & & $\mathrm{Gd}$ & & $\mathrm{Hf}$ & $\mathrm{Pu}$ \\
\hline $\begin{array}{c}\text { Sample } \\
\text { ID }\end{array}$ & $\left(\mathrm{m}^{-1}\right)$ & $\left(\mathrm{g} / \mathrm{m}^{2}\right)$ & & $\left(\mathrm{g} / \mathrm{m}^{2}\right)$ & $\left(\mathrm{g} / \mathrm{m}^{2}\right)$ & $\left(\mathrm{g} / \mathrm{m}^{2}\right)$ & & $\left(\mathrm{g} / \mathrm{m}^{2}\right)$ & & $\left(\mathrm{g} / \mathrm{m}^{2}\right)$ & & $\left(\mathrm{g} / \mathrm{m}^{2}\right)$ & $\left(\mathrm{g} / \mathrm{m}^{2}\right)$ \\
\hline $\mathrm{Pu}-7$ & 1,502 & $1.6 \mathrm{E}-02$ & $<$ & $9.8 \mathrm{E}-03$ & $1.0 \mathrm{E}-02$ & $2.2 \mathrm{E}-03$ & & $6.9 \mathrm{E}-04$ & & $4.2 \mathrm{E}-04$ & $<$ & $2.6 \mathrm{E}-06$ & $3.7 \mathrm{E}-03$ \\
\hline Pu-B-7* & 20,700 & $6.7 \mathrm{E}-03$ & & 4.4E- 03 & $8.8 \mathrm{E}-03$ & 2.1E-04 & & $8.8 \mathrm{E}-05$ & & $6.4 \mathrm{E}-05$ & $<$ & 7.3E-06 & $1.2 \mathrm{E}-03$ \\
\hline $\mathrm{Pu}-8$ & 1,508 & $6.5 \mathrm{E}-03$ & & $1.0 \mathrm{E}-02$ & 8.7E-03 & 5.4E-06 & $<$ & 4.2E-06 & $<$ & 4.2E-05 & $<$ & $2.6 \mathrm{E}-06$ & $2.6 \mathrm{E}-03$ \\
\hline Pu-B-14 & 20,818 & $7.2 \mathrm{E}-03$ & $<$ & 4. $4 \mathrm{E}-03$ & $8.5 \mathrm{E}-03$ & 7.9E-05 & & 8.9E-05 & & 3.7E-05 & & $1.3 \mathrm{E}-05$ & $1.2 \mathrm{E}-03$ \\
\hline
\end{tabular}

* Average of Pu-B-7 and Pu-B-7-rep

Table 13. Average Normalized Releases $\left(G r a m s ~ G l a s s / m^{2}\right)$ in PCT-A Tests at SA/V Ratios of 1500 - Steel and Teflon ${ }^{\circledR}$

\begin{tabular}{|c|c|c|c|c|c|c|c|c|c|c|c|c|c|}
\hline & $\mathrm{SA} / \mathrm{V}$ & $\mathrm{B}$ & & $\mathrm{Si}$ & $\mathrm{Sr}$ & & $\mathrm{Al}$ & $\mathrm{La}$ & $\mathrm{Nd}$ & $\mathrm{Gd}$ & & $\mathrm{Hf}$ & $\mathrm{Pu}$ \\
\hline Sample ID & $\left(\mathrm{m}^{-1}\right)$ & $\left(\mathrm{g} / \mathrm{m}^{2}\right)$ & & $\left(\mathrm{g} / \mathrm{m}^{2}\right)$ & $\left(\mathrm{g} / \mathrm{m}^{2}\right)$ & & $\left(\mathrm{g} / \mathrm{m}^{2}\right)$ & $\left(\mathrm{g} / \mathrm{m}^{2}\right)$ & $\left(\mathrm{g} / \mathrm{m}^{2}\right)$ & $\left(\mathrm{g} / \mathrm{m}^{2}\right)$ & & $\left(\mathrm{g} / \mathrm{m}^{2}\right)$ & $\left(\mathrm{g} / \mathrm{m}^{2}\right)$ \\
\hline Pu-1 - Pu-3 & 1,500 & $1.2 \mathrm{E}-02$ & $<$ & $9.8 \mathrm{E}-03$ & $1.1 \mathrm{E}-02$ & $<$ & $1.0 \mathrm{E}-03$ & $4.7 \mathrm{E}-04$ & $1.2 \mathrm{E}-04$ & $6.3 \mathrm{E}-05$ & & $6.2 \mathrm{E}-06$ & $3.0 \mathrm{E}-03$ \\
\hline $\begin{array}{l}\mathrm{Pu}-1 \text { - Pu-3 } \\
\text { Std.Dev. }\end{array}$ & 1,500 & $8.5 \mathrm{E}-04$ & & NA & 7.7E-04 & & NA & $9.9 \mathrm{E}-05$ & $3.3 \mathrm{E}-05$ & $1.7 \mathrm{E}-05$ & & $5.3 \mathrm{E}-06$ & $2.9 \mathrm{E}-04$ \\
\hline $\mathrm{Pu}-7$ & 1,502 & $1.6 \mathrm{E}-02$ & $<$ & $9.8 \mathrm{E}-03$ & $1.0 \mathrm{E}-02$ & $<$ & $1.0 \mathrm{E}-03$ & $2.2 \mathrm{E}-03$ & $6.9 \mathrm{E}-04$ & 4.2E-04 & $<$ & $2.6 \mathrm{E}-06$ & $3.7 \mathrm{E}-03$ \\
\hline
\end{tabular}

Table 14. Average Normalized Releases (Grams Glass/ $\mathbf{m}^{2}$ ) in PCT Tests at SA/V Ratio of $21000 \mathrm{~m}^{-1}$ in Teflon Vessels from 7 to 56 Days

\begin{tabular}{|c|c|c|c|c|c|c|c|c|c|c|c|}
\hline & $\mathrm{SA} / \mathrm{V}$ & $\mathrm{B}$ & & $\mathrm{Si}$ & $\mathrm{Sr}$ & $\mathrm{La}$ & $\mathrm{Nd}$ & $\mathrm{Gd}$ & & $\mathrm{Hf}$ & $\mathrm{Pu}$ \\
\hline Sample ID & $\left(\mathrm{m}^{-1}\right)$ & $\left(\mathrm{g} / \mathrm{m}^{2}\right)$ & & $\left(\mathrm{g} / \mathrm{m}^{2}\right)$ & $\left(\mathrm{g} / \mathrm{m}^{2}\right)$ & $\left(\mathrm{g} / \mathrm{m}^{2}\right)$ & $\left(\mathrm{g} / \mathrm{m}^{2}\right)$ & $\left(\mathrm{g} / \mathrm{m}^{2}\right)$ & & $\left(\mathrm{g} / \mathrm{m}^{2}\right)$ & $\left(\mathrm{g} / \mathrm{m}^{2}\right)$ \\
\hline Pu-B-7* & 20,700 & $6.7 \mathrm{E}-03$ & & 4.4E-03 & $8.8 \mathrm{E}-03$ & 2.1E-04 & $8.8 \mathrm{E}-05$ & 6.4E-05 & $<$ & 7.3E-06 & $1.2 \mathrm{E}-03$ \\
\hline $\mathrm{Pu}-\mathrm{B}-14$ & 20,818 & $7.2 \mathrm{E}-03$ & $<$ & $4.4 \mathrm{E}-03$ & $8.5 \mathrm{E}-03$ & $7.9 \mathrm{E}-05$ & $8.9 \mathrm{E}-05$ & $3.7 \mathrm{E}-05$ & & $1.3 \mathrm{E}-05$ & $1.2 \mathrm{E}-03$ \\
\hline Pu-B-28 & 20,590 & $1.2 \mathrm{E}-02$ & & $6.3 \mathrm{E}-03$ & $1.0 \mathrm{E}-01$ & 2.9E-05 & $1.6 \mathrm{E}-05$ & 2.4E-05 & & 7.9E-06 & $1.0 \mathrm{E}-03$ \\
\hline Pu-B-56 & 20,695 & $2.0 \mathrm{E}-02$ & & $1.1 \mathrm{E}-02$ & $1.3 \mathrm{E}-02$ & $3.1 \mathrm{E}-05$ & $5.2 \mathrm{E}-05$ & $3.4 \mathrm{E}-05$ & & $5.9 \mathrm{E}-06$ & $2.1 \mathrm{E}-03$ \\
\hline
\end{tabular}

* Average of Pu-B-7 and Pu-B-7-rep 
Table 15. Average Normalized Releases $\left(\right.$ Grams Glass $\left./ \mathrm{m}^{2}\right)$ in PCT-A and PCT-B Tests Comparing Filtered vs. Ultrafiltered

\begin{tabular}{|c|c|c|c|c|c|c|c|c|c|c|}
\hline Sample ID & $\operatorname{SA} / \mathrm{V}\left(\mathrm{m}^{-1}\right)$ & $\mathrm{La}\left(\mathrm{g} / \mathrm{m}^{2}\right)$ & & $\mathrm{Nd}\left(\mathrm{g} / \mathrm{m}^{2}\right)$ & & $\mathrm{Gd}\left(\mathrm{g} / \mathrm{m}^{2}\right)$ & & $\mathrm{Hf}\left(\mathrm{g} / \mathrm{m}^{2}\right)$ & $\mathrm{Pu}\left(\mathrm{g} / \mathrm{m}^{2}\right)$ & $\begin{array}{l}\text { \% Diff. Filt. } \\
\text { Vs. Ultrafilter } \\
(\mathrm{Pu})^{* * *}\end{array}$ \\
\hline Pu-1 - Pu-3 & 1,500 & $4.7 \mathrm{E}-04$ & & $1.2 \mathrm{E}-04$ & & $6.3 \mathrm{E}-05$ & & $6.2 \mathrm{E}-06$ & $3.0 \mathrm{E}-03$ & 11 \\
\hline $\begin{array}{l}\mathrm{Pu}-1 \text { - Pu-3 } \\
\text { Std.Dev. }\end{array}$ & 1,500 & $9.9 \mathrm{E}-05$ & & 3.3E-05 & & 1.7E-05 & & $5.3 \mathrm{E}-06$ & $2.9 \mathrm{E}-04$ & \\
\hline $\begin{array}{c}\mathrm{Pu}-1 \text { - Pu-2 } \\
\text { UF * }\end{array}$ & 1,500 & 1.6E-05 & $<<$ & 9.7E-05 & $<$ & $3.5 \mathrm{E}-04$ & $<$ & 4.5E-05 & $2.6 \mathrm{E}-03$ & \\
\hline $\begin{array}{c}\text { Pu-1 - Pu-2 UF } \\
\text { Std.Dev. }{ }^{*}\end{array}$ & 1,500 & $8.0 \mathrm{E}-06$ & & $5.4 \mathrm{E}-08$ & & 2.0E-07 & & $2.5 \mathrm{E}-08$ & $2.0 \mathrm{E}-04$ & \\
\hline$P u-4-P u-6$ & 2,100 & $1.9 \mathrm{E}-04$ & & $4.8 \mathrm{E}-05$ & & $3.1 \mathrm{E}-05$ & & $2.8 \mathrm{E}-06$ & $2.5 E-03$ & 6 \\
\hline $\begin{array}{l}\text { Pu-4 - Pu-6 } \\
\text { Std.Dev. }\end{array}$ & 2,100 & 1.1E-04 & & $2.3 \mathrm{E}-05$ & & $6.2 \mathrm{E}-06$ & & $1.1 \mathrm{E}-06$ & $1.8 \mathrm{E}-04$ & \\
\hline $\begin{array}{c}\text { Pu-4 - Pu-6 } \\
\text { UF } \\
\end{array}$ & 2,100 & 3.3E-04 & & 3.0E-04 & & $2.9 \mathrm{E}-04$ & & 2.0E-04 & 2.4E-03 & \\
\hline $\begin{array}{c}\text { Pu-4 - Pu-6 UF } \\
\text { Std.Dev. }\end{array}$ & 2,100 & $2.9 \mathrm{E}-04$ & & 2.3E-04 & & $8.2 \mathrm{E}-05$ & & $1.6 \mathrm{E}-04$ & $2.3 \mathrm{E}-04$ & \\
\hline $\mathrm{Pu}-7$ & 1,502 & $2.2 \mathrm{E}-03$ & & $6.9 \mathrm{E}-04$ & & $4.2 \mathrm{E}-04$ & $<$ & $2.6 \mathrm{E}-06$ & $3.7 \mathrm{E}-03$ & 6 \\
\hline Pu-7 UF & 1,502 & $1.0 \mathrm{E}-03$ & & $2.6 \mathrm{E}-04$ & & $1.5 \mathrm{E}-04$ & $<$ & $3.9 \mathrm{E}-05$ & $3.4 \mathrm{E}-03$ & \\
\hline Pu-8 & 1,508 & $5.4 \mathrm{E}-06$ & $<$ & $4.2 \mathrm{E}-06$ & $<$ & $4.2 \mathrm{E}-05$ & $<$ & $2.6 \mathrm{E}-06$ & $2.6 \mathrm{E}-03$ & $\overline{10}$ \\
\hline Pu-8 UF & 1,508 & $3.2 \mathrm{E}-05$ & $<$ & 9.5E-05 & $<$ & $3.5 \mathrm{E}-04$ & $<$ & $3.9 \mathrm{E}-05$ & $2.4 E-03$ & \\
\hline Pu-B-7** & 20,700 & $2.1 \mathrm{E}-04$ & & $8.8 \mathrm{E}-05$ & & $6.4 \mathrm{E}-05$ & $<$ & $7.3 \mathrm{E}-06$ & 1.2E-03 & $\overline{0}$ \\
\hline Pu-B-7 UF** & 20,700 & $1.9 \mathrm{E}-04$ & & $6.8 \mathrm{E}-05$ & & $4.5 \mathrm{E}-05$ & $<$ & $8.4 \mathrm{E}-06$ & $1.2 \mathrm{E}-03$ & \\
\hline Pu-B-14 & 20,818 & $7.9 \mathrm{E}-05$ & & 8.9E-05 & & $3.7 \mathrm{E}-05$ & & 1.3E-05 & $1.2 E-03$ & -4 \\
\hline Pu-B-14 UF & 20,818 & $2.2 \mathrm{E}-05$ & & $1.4 \mathrm{E}-05$ & & $5.0 \mathrm{E}-06$ & & $6.9 \mathrm{E}-06$ & 1.3E-03 & \\
\hline Pu-B-28 & 20,590 & $2.9 \mathrm{E}-05$ & & $1.6 \mathrm{E}-05$ & & $2.4 \mathrm{E}-05$ & & $7.9 \mathrm{E}-06$ & $1.0 \mathrm{E}-03$ & 16 \\
\hline Pu-B-28 UF & 20,590 & $2.1 \mathrm{E}-05$ & & $1.2 \mathrm{E}-05$ & & $3.8 \mathrm{E}-05$ & & $6.9 \mathrm{E}-06$ & $8.8 \mathrm{E}-04$ & \\
\hline Pu-B-56 & 20,695 & $3.1 \mathrm{E}-05$ & & $5.2 \mathrm{E}-05$ & & $3.4 \mathrm{E}-05$ & & $5.9 \mathrm{E}-06$ & $2.1 E-03$ & 8 \\
\hline Pu-B-56 UF & 20,695 & $1.4 \mathrm{E}-04$ & & $1.1 \mathrm{E}-04$ & & $6.5 \mathrm{E}-05$ & & $6.4 \mathrm{E}-05$ & 1.9E-03 & \\
\hline
\end{tabular}

${ }^{*}$ Pu-3 was not ultrafiltered

** Average of Pu-B-7 and Pu-B-7-rep

${ }^{* * *}(($ Filt. - UF $) / F i l t) \times$. 


\subsubsection{Examination of PCT-B Leached Pu Glass After 28 and 56 Days}

Following the PCT-B testing, samples of leached glass were obtained from the 28 and 56 day exposure tests for analysis. The SEM results again showed no evidence of alteration phase formation on the glass surface, however, the undissolved $\mathrm{PuO}_{2}$ disk-like phase was evident on some glass grains (Figure 8).

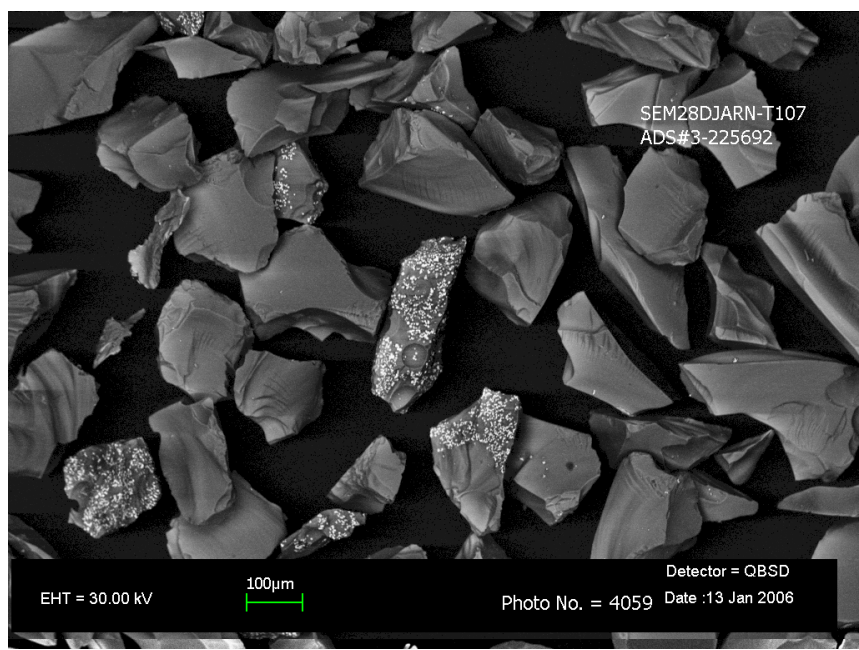

28 day leached Pu LaBS Glass

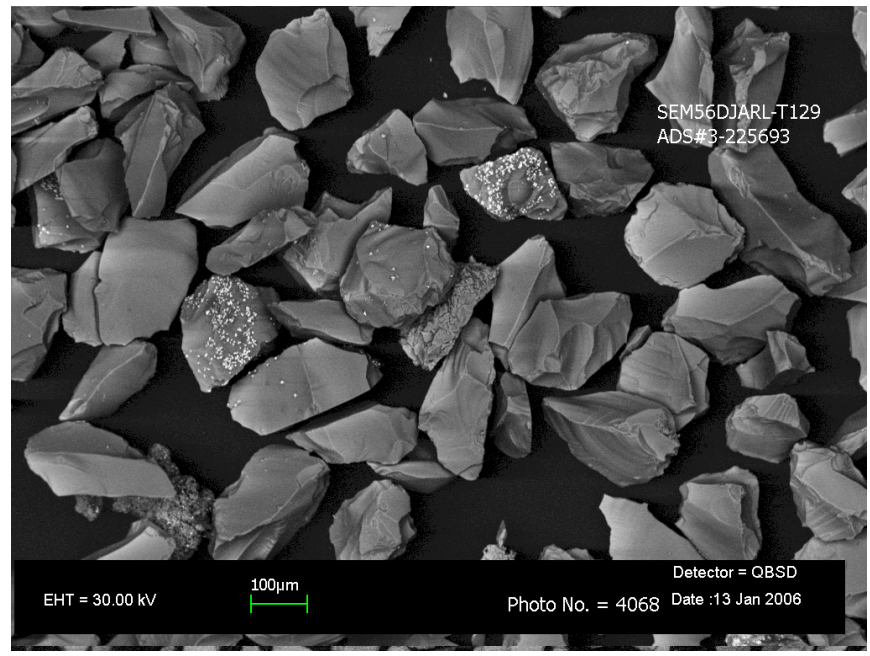

56 day leached Pu LaBS Glass

Figure 8. SEM micrographs of 28 and 56 day leached Pu LaBS glass showing undissolved $\mathrm{PuO}_{2}$ crystals but no alteration phase formation 


\subsubsection{Acid-Stripping of PCT Vessels}

All data presented in the previous sections pertain to filtered and ultrafiltered leachate data only. In addition to leachate analyses, all of the PCT vessels were acid-stripped in this study and have been submitted for both ICP-AES and ICP-MS analyses. All of the acid strip data is not complete at this time. However some preliminary observations can be made. Enrichment of plutonium from the acid strip solutions vs. any of the other glass elements was not observed. All of the acid strip solutions showed detectable amounts of all the elements in the glass. This observation along with the varying concentrations found in the acid strip solutions analyzed to date, indicated that trace levels of glass could have been present in the PCT vessels before acid stripping. Converting the analyzed amount of the elementals in the acid strip solutions to calculated glass shows that about $0.1 \mathrm{mg}$ to $1 \mathrm{mg}$ of glass was present in the combined strip solutions from the three successive acid strips of the vessels. A full comparison of the filtered leachates and the acid strip solutions will be completed as soon as all of the acid strip data is available. 
WSRC-TR-2006-00033

Revision 0

This page intentionally left blank. 


\subsection{CONCLUSIONS}

Plutonium containing LaBS Frit B composition glass was fabricated, analyzed and leach tested in this task. The following conclusions can be drawn from the testing:

- A small amount of undissolved $\mathrm{PuO}_{2}$ was present in the glass after fabrication. The undissolved particles had a disk-like morphology and likely formed via coarsening of particles in areas compositionally enriched in plutonium. Similar disk-like $\mathrm{PuO}_{2}$ phases were observed in previous LaBS glass testing at PNNL. In that work, researchers concluded that plutonium formed with this morphology as a result of the leaching process. It was more likely that the presence of the plutonium oxide crystals in the PNNL testing was a result of glass fabrication.

- PCT-A results on the Pu containing LaBS Frit B glass showed that the glass was very durable and was better than two orders of magnitude more durable from a boron release standpoint than the current Environmental Assessment (EA) glass used for repository acceptance.

- The normalized elemental release values for the PCT-B tests were comparable with the PCT-A results, again indicating the relative good durability exhibited by this glass.

- Comparison of the initial syringe-filtered leachates to the ultrafiltered leachates indicated that normalized plutonium releases were essentially the same within the analytical uncertainty of the ICP-MS methods used to quantify plutonium in the leachates. These results indicated that colloidal plutonium species did not form under the PCT conditions used in this study. 
WSRC-TR-2006-00033

Revision 0

This page intentionally left blank. 


\subsection{RECOMMENDATIONS / PATH FORWARD}

Several items were identified in this testing indicating where further analysis and testing are needed. PCT-B testing should be conducted for longer durations (as planned) on the Frit B composition and other candidate compositions (e.g. the Frit X glass that has been identified in other recent Pu glass testing ${ }^{15}$ ) to provide additional insight into colloid and alteration phase formation.

Due to discrepancies in the glass composition analytical data, the normalized release data provided in this report were based on targeted glass composition values. Although, it is expected to only have a minor impact on the calculations (the current analytical data set shows that no glass constituent varies from the targeted value by more than approximately $30 \%$ and most varied by less than $10 \%$ ), the glass compositional data should be finalized to complete the data set. The vessel strip data obtained in this testing was not used in the elemental release calculations. The results obtained indicated that plutonium did not appear to be preferentially sorbed on the leach vessel surfaces. However, due to the extremely low release values for this glass, the actual contribution of sorption to the glass release values could not be quantified. Improved vessel cleaning and strip methods need to be investigated if strip data is deemed important for future testing. 
WSRC-TR-2006-00033

Revision 0

This page intentionally left blank. 


\subsection{ACKNOWLEDGEMENTS}

The authors wish to acknowledge many colleagues who contributed to the completion of this effort. Irene Reamer and Phyllis Workman prepared the frit needed to prepare the plutonium glass. Dave Best and Pat Toole performed the surrogate glass chemical analyses in the SRNL Mobile Laboratory. Tracy Rudisill provided the $\mathrm{PuO}_{2}$ to make the plutonium glass and directed the analyses and interpretation of the results on the $\mathrm{PuO}_{2}$ material. Mona Galloway prepared the plutonium glasses and Phyllis Burkhalter performed the glass density and PCTs on the Pu glasses in the shielded cells facility. Sherry Vissage, Debbie Marsh, Irene Reamer, and Joe Wheeler performed the leachate filtrations and prepared the leachate solutions for analyses. Mike Summer and Jack Durden performed the SEM analyses and Art Jurgensen and David Missimer performed the XRD analyses. June Hart was responsible for the radioactive ICP-AES analyses and Curtis Johnson directed the ICP-MS analyses. David Diprete performed the liquid scintillation and gamma counting analyses.

The authors would also like to thank Bill Ebert of ANL and Denis Strachan of PNNL for technical advice and fruitful discussions regarding this work.

Finally, the authors would like to than Mimi Jones for her support in the technical editing of this report. 
WSRC-TR-2006-00033

Revision 0

This page intentionally left blank. 


\subsection{REFERENCES}

1 "Standard Test Methods for Determining Chemical Durability of Nuclear, Hazardous, and Mixed Waste Glasses and Multiphase Glass Ceramics: The Product Consistency Test (PCT)," American Society for Testing and Materials (ASTM), ASTM C1285-02, West Conshohoken, PA. 2002.

2 "Waste Acceptance Product Specifications for Vitrified High-Level Waste Forms," U.S. Department of Energy, Office of Environmental Management, USDOE Document EM-0093, Revision 2, Washington, DC, 1996.

3 "Defense HLW Glass Degradation," Bechtel SAIC Company, Report ANL-EBS-MD-000016 Rev 01, Las Vegas, NV, 2003.

${ }^{4}$ Bibler, N. E., W. G. Ramsey, T. F. Meaker, and J. M. Pareizs, "Durabilites and Microstructures of Radioactive Glasses for Immobilization of Excess Actinides at the Savannah River Site," Mat. Res. Soc. Symp. Proc., Vol. 412, Materials Research Society, Pittsburgh, PA, 1995.

5 Meaker, T. F., W. G. Ramsey, J. M. Pareizs, and D. G. Karraker, "Composition Development for Vitreous Plutonium Products," Environmental and Waste Management Issues in the Ceramic and Nuclear Industries II, Ceramic Transactions, Vol. 72, American Ceramic Society, Westerville, OH, 1996.

6 Mertz, C. J., A. J. Bakel, J. K. Bates, D. B. Chamberlain, J. A. Fortner, J. M. Hanchar, and S. F. Wolf, "Comparison of the Corrosion Behavior of Plutonium Glasses," Environmental and Waste Management Issues in the Ceramic and Nuclear Industries VI, Ceramic Transactions, Vol. 87, American Ceramic Society, Westerville, OH, 1998.

7 Meaker, T. F. and N. E. Bibler, "Comparison of the Durabilities and Microstructures of an Amorphous and Devitrified Plutonium Bearing Lanthanide Borosilicate Glass (U)," contained in Plutonium Immobilization: The Glass Option - A Compendium of Reports and Presentations, WSRC-RP-9700902, Westinghouse Savannah River Company, Aiken, SC, 1997.

8 Meaker, T. F. and N. E. Bibler, "Characterization and Product Consistency Leach Tests of Lanthanide Borosilicate Glasses Containing Plutonium and Uranium or Impurities (U)," contained in Plutonium Immobilization: The Glass Option - A Compendium of Reports and Presentations, WSRC-RP-9700902, Westinghouse Savannah River Company, Aiken, SC, 1997.

${ }^{9}$ Personal communication with Tracy Rudisill, Savannah River National Laboratory, 2005.

${ }^{10}$ Vienna, J. D., D. L. Alexander, H. Li, M. J. Schweiger, D. K. Peeler, and T. F. Meaker, "Plutonium Dioxide Dissolution in Glass," PNNL-11346, UC-510, Pacific Northwest National Laboratory, Richland, WA, 1996.

${ }^{11}$ Pierce, E. M., B. P. McGrail, P. F. Martin, B. W. Arey, and K. N. Geizler, “Accelerated Weathering of High-Level and Plutonium-bearing Lanthanide Borosilicate Waste Glasses in a Can-in-Canister Configuration under Hydraulically Unsaturated Conditions," Submitted for publication in the Journal of Nuclear Materials, Pacific Northwest National Laboratory, Richland, WA, 2005. 
${ }^{12}$ Jantzen, C. M., N. E. Bibler, D. C. Beam, C. L. Crawford and M. A. Pickett, "Characterization of the Defense Waste Processing Facility (DWPF) Environmental Assessment (EA) Glass Standard Reference Material (U)," WSRC-TR-92-346, Rev. 1, 1993.

${ }^{13}$ Mellinger, G. B. and J. L. Daniel, “Approved Reference and Testing Materials for Use in Nuclear Waste Management Research and Development Programs," PNL-4955-1, Pacific Northwest Laboratory, December, 1983.

${ }^{14}$ Jantzen, C. M., M. A. Pickett, K. G. Brown, T. B. Edwards, and D. C. Beam, "Process/Product Models for the DWPF: Part 1. Predicting the glass Durability from Composition Using a Thermodynamic Energy Hydration Model (THERMO) (U)," Volume 2: Appendix G, Pages G9 - G11, WSRC-TR-93672, Rev. 1, 1995.

${ }^{15}$ Marra, J. C., D. K. Peeler, and C. M. Jantzen, "Development of an Alternative Glass Formulation for Vitrification of Excess Plutonium," WSRC-TR-2006-00031, Washington Savannah River Company, Aiken, SC, 2006. 